\title{
No contagion from Russia toward global equity markets after the 2014 international sanctions
}

\author{
G. Castagneto-Gissey ${ }^{a, b}$, E. Nivorozhkin
}

This paper examines the possibility of financial contagion from the Russian stock market toward 18 global markets due to the international sanctions resulting from Russia's actions in Crimea. We develop a z-transform dynamic heteroskedastic procedure to determine the potential degrees of contagion and explore possible volatility spillovers. Among our main results, the Russian market substantially decoupled from the vast majority of world markets, irrespectively of the strength of economic ties between Russia and the corresponding countries. Yet, the crisis was characterized by large transmissions of volatility associated with the Russian market, particularly in emerging and frontier economies.

JEL classification: F30, E30, C32, F42.

Keywords: financial contagion, equity market, Ukrainian crisis, volatility spillover, sanctions.

Author affiliations: aUniversity College London, SSEES Economics and Business Group, UCL Centre for Comparative Studies of Emerging Economies (CSEE); ${ }^{b}$ University College London, The Bartlett, Central House, 14 Upper Woburn Place, London WC1H ONN, UK.

Corresponding author details: Giorgio Castagneto-Gissey, 16 Taviton Street, London WC1H 0BW, United Kingdom, g.castagneto-gissey@ucl.ac.uk, +44 (0)2076798772. 


\section{Introduction}

This paper represents the first attempt to investigate the consequences of the Russian involvement in the 2014 Ukrainian crisis. We examine the dramatic developments in Ukraine vis-àvis their effects on the behavior of the Russian stock market by studying the changes in the dynamic interactions between Russian stock index returns and those from a representative sample of emerging, frontier and developed markets. Our main aim is to unveil the question of financial contagion from the Russian market, particularly on markets from countries with relatively strong economic ties to Russia. The subject of the paper is at the heart of financial literature and recently received renewed attention in the context of the 2008 global financial crisis (e.g. Bekaert et al., 2009; Bekaert et al., 2014, Miguel and Polk, 2014) and the European sovereign debt crisis (Missio and Watzka, 2011; Mink and De Haan, 2013).

We employ the dynamic (DCC) and the varying conditional correlation (VCC) AR-MGARCH models and apply Fisher's z-transformation to test for changes in the dynamics of volatilityunconditional correlations between the returns on the Russia stock market and 18 emerging, frontier and developed equity markets. Our results reveal that the degree of co-movement between Russian index returns and the returns in the vast majority of international markets significantly declined in the aftermath of the Ukrainian crisis. Contrary to our expectations, the results for countries with closer economic ties to Russia are in line with the general trend during this period, indicating effectively no transmission channel via increased co-movement of stock returns. In fact, the last time Russian stock returns were so weakly associated with global market returns was in the period 2002-04, when the Russian market was hardly on the radars of international portfolio investors. Nevertheless, we also show that for a number of frontier and emerging economies that large volatility spillovers associated with the Russian market occurred and that the crisis period coincided with the appearance of asymmetric effects in a substantial proportion of considered markets.

In consideration of the factors potentially affecting current developments in the Russian market, our results suggest that an increased advantage of including Russian stocks in internationally diversified equity investment portfolios is unlikely. In the background of still being regarded as a major emerging market, the Russian stock market's declining capitalization and decreasing free-float led to a dramatic drop in Russia's weight in investable equity indices, such as the MSCI Emerging Markets Index. For example, the weight of the Russian stocks in iShares $\mathrm{MSCl}$ Emerging Markets ETF, which tracks the MSCI Emerging Markets Index, dropped to 3.76\%, lagging 
behind markets such as Mexico, South Africa, and Brazil ${ }^{1}$. In view of the limited choice of investments due to the sanctions imposed on Russia, the decreased co-movement of the Russian market with the rest of the world is unlikely to provide investors with superior diversification opportunities. On the other hand, if the sanctions are limited, a large flow of equity portfolio investments is likely to be observed, given that the market is currently very cheap according to investors. ${ }^{2}$

The remainder of the paper is organized as follows. Section 2 provides the background to the Ukrainian crisis and discusses the potential channels of contagion, section 3 reviews the relevant literature, section 4 analyses the data, while section 5 outlines the methodologies used in this work. Finally, section 6 reports our findings, section 7 discusses them and presents policy appraisals, whereas section 8 provides the main conclusions.

\section{The Ukrainian crisis and the channels of contagion from the Russian market}

A wave of demonstrations and civil unrest in Ukraine, which began on the night of 21 November 2013 culminated with the Parliament removing President Yanukovych from office and replacing his government with a pro-European one on 22 February 2014, resulting in the Crimean crisis beginning amid pro-Russian unrest. By the end of February, pro-Russian gunmen seized key buildings in Crimean capital Simferopol and unidentified gunmen in combat uniforms appeared outside Crimea's main airports. Following Russia's parliament approval of President Vladimir Putin's request to use forces in Ukraine to protect Russian interests on 1 March, Crimea's secession referendum on joining Russia, widely viewed as illegitimate, was conducted on 16 March and backed by $97 \%$ of voters. Shortly after, on 18 March, President Putin signed a bill to absorb Crimea into the Russian Federation. Since then, the economic development of the Russian Federation was heavily affected by the consequences of the political and security crisis in Ukraine. Already in March 2014, the Ukrainian crisis prompted a number of governments to apply sanctions against individuals, businesses and officials from Russia, followed by several rounds of ever tighter sanctions approved by the European Union, the United States, as well as other countries and international organizations. In addition to diplomatic actions, the measures included travel bans and asset freezes against Russian officials, including a broad set of measures targeting sectorial cooperation and exchanges with Russia, including additional measures concerning general economic cooperation. In particular, Russian state banks were excluded from raising long-term loans, there were bans on arms deals, exports of dual-use equipment for military use, and an EU-US ban on exports of some oil industry technology and services, just to name a few. Unsurprisingly, the under-diversified and highly concentrated nature of the Russian economy characterized by pervasive state control, led to a devastating effect of sanctions beyond the targeted sectors. Moreover, Russia responded with a list of reciprocal sanctions and embargos for a one-year period on imports of most of the agricultural

\footnotetext{
${ }^{1}$ More information available at: https://www.ishares.com/us/products/239637/ishares-msci-emerging-markets-etf.

2 More information available at: http://www.cnbc.com/2015/02/24/this-years-best-performing-stock-market-isrussia.html.
} 
products whose country of origin had either "adopted the decision on introduction of economic sanctions in respect of Russian legal and (or) physical entities, or joined same". ${ }^{3} \mathrm{~A}$ dramatic turbulence in Russian financial markets and a major slowdown of the Russian economy in the aftermath of the sanctions, which revealed already weak fundamentals, were expected to have a large impact on a number of economies with strong economic ties to Russia. Eastern European countries (including the Commonwealth of Independent States [CIS]), which have the closest links with Russia, were the most prone to be seriously affected by a sharp slowdown of the Russian economy or the implementation of sanctions and countersanctions (IMF, 2014). Although Western European countries tend to be relatively less linked to Russia, some of them were also expected to foresee noteworthy effects.

The broad channels by which these countries are connected to Russia include their trade, energy, investment, and financial ties. The exposure of exports to the Russian market is a significant issue for many of Russia's immediate neighbors such as Belarus, Ukraine, Moldova, and the Baltic countries. These countries' exports to Russia tend to exceed 5 percent of their respective GDP, making such economies potentially vulnerable to slowdowns in Russia.

Western European countries' trade exposure is typically related to the import of gas and oil from Russia, but some industries (e.g. chemicals and minerals, metals, and manufacturing equipment) also rely heavily on imported production inputs from Russia. Moreover, Russia supplies about one third of Europe's natural gas. The share of total gas consumption from Russia is over 50 percent in virtually all Eastern European countries as well as several advanced economies in Europe. The share of Russian supplies in total energy consumption in Europe is moderately smaller, but still very important. Russian oil imports also tend to be substantial for many European countries, although potential supply disruptions are simpler to overcome than those for gas imports. Overall, "the energy channel" of Russian influence, via a price increase or disruption in gas supplies, depends on trade partners' ability to access alternative suppliers or energy sources and is likely to vary significantly across countries. In terms of investment flows, by the end of the 2000s Russia became the second largest foreign direct investor among emerging markets and, for some countries, foreign direct investments (FDI) from Russia tends to exceed 5 percent of GDP (e.g. Ukraine, Bulgaria). ${ }^{4}$ These FDI amounts are often as much politically as commercially driven, but are likely to dry out as a result of lower profits of Russian businesses and banks, lacking access to cheap foreign credit as a consequence of Western sanctions. The Russian government is also likely to take a less generous approach to the various loans, grants and debt-write offs, often used to support its plans to enhance its position as regional hegemon (EIU, 2014). Some developed economies, among which stands the Netherlands, have significant inward FDI into Russia, while many other financial centers are

\footnotetext{
${ }^{3}$ Presidential Decree of August 6, 2014 N 560 "On the application of certain special economic measures to ensure the security of the Russian Federation". www.Garant.ru (in Russian language).

${ }^{4}$ It should be noted that these amounts are likely to underestimate the actual level of investment flows from Russia, as some transfers are not recorded as FDI.
} 
characterized by two-way FDI flows with Russia. In terms of financial links, a large number of Western banks have considerable exposures to Russia. For example, many Hungarian and French banks are exposed to Russia both because of the prevalence of their subsidiaries in Russia as well as their direct lending to Russian customers from outside the Federation. For some of these banks, the share of profits from Russian operations has increased in excess of 30 percent within the last few years (IMF, 2014). Importantly, the slowdown in Russia is likely to generate negative externalities, as the same Western banks tend to lend to other countries in Central, Eastern and South-Eastern Europe (CESEE). Finally, foreign portfolio investments to Russia are also notable, given that Russian assets account for 5-12 percent of emerging market benchmark indices.

Overall, the channels by which some countries are connected to Russia, discussed above, point out to the potential risk of contagion from the Russian stock market, thereby motivating our focus on the change in the degree of co-movement between the Russian and other stock markets.

\section{Literature review}

The following section provides a short overview of the literature on financial contagion from both theoretical and empirical perspectives. We highlight the models used to test for contagion, discuss the methodological issues and present a summary of previous work on this topic.

Current empirical studies of financial contagion derive from Sharpe (1964), as well as Grubel and Fadner (1971), King and Wadhwani (1990), Engle et al. (1990), Bekaert and Hodrick (1992) and, particularly, Forbes and Rigobon (2002). Although financial contagion does not have a widely accepted definition, most studies define it as a significant increase in volatility-unbiased cross-market movements during a crisis period (e.g. Forbes and Rigobon, 2002, Celik, 2012, Gentile and Giordano, 2012). According to the definition used in this paper, contagion only occurs when market co-movement increases significantly after the crisis date, defined in our case by Russia's annexation of Crimea ${ }^{5}$. If the co-movement between markets does not increase significantly, a strong interdependence is simply evidence of robust linkages between two economies that exist in all states of the world.

The feature which differentiates the large variety of empirical models on contagion is represented by the way in which the available information is used to detect contagion (Dungey et al., 2005). For example, Favero and Giavazzi (2002) use a set of shift dummies at selected crisis points to measure the transmission of contagious shocks. Forbes and Rigobon (2002) use overlapping periods and distinct samples to define the pre- and post-crisis periods to test for the presence of contagion. Eichengreen et al. $(1995,1996)$ also make use of binary variables to recognize contagion, whereas they provide a transformation of both the dependent and the explanatory variables into

\footnotetext{
${ }^{5}$ Russia's claims in support of the expropriation of Ukraine's Crimean territory have taken various forms, however regardless of the claim adopted by Russia, its position lacks justification under international law. In fact, under the Charter of the United Nations' basic principles (http://www.un.org/en/documents/charter/), states could only use armed forces collectively for security measures (Article 42) or in selfdefense (Article 51). Any other use of forces was defined as a breach of international law: we therefore refer to the event as an annexation rather than secession.
} 
dummy variables. Bae et al. (2003) add to the Eichengreen et al. (1996) model by allowing for a polychotomous explained variable, based on a crisis indicator and the number of its co-exceedances, and provide evidence of enhanced model parsimony. A survey of empirical techniques used to analyze contagion can be found in Dungey et al. (2010).

So far, a large number of techniques have been used to measure the transmission of financial shocks. These can be classified in the four broad categories: analysis of cross-market correlation coefficients, GARCH frameworks, co-integration models and probit models. In this paper we use the first two approaches - cross-market correlations are analyzed using the rolling six-monthly window correlations, whereas models from the $\mathrm{GARCH}$ family are employed to model stock returns and volatilities.

The theoretical literature explaining how shocks spread across international markets is similarly well developed. A number of theories exist which hypothesize why contagion could occur. Claessens and Forbes (2004) divide this literature into two broad groups. The first group focuses on fundamental causes, such as common shocks, trade or financial linkages. The second group pays more attention to investors' behavior, including liquidity concerns, incentive problems, information asymmetries, market coordination problems and investor sentiment. We focus on a novel idea of contagion because it derives from purely political concerns, thereby feeding into both financial markets (equity and currency markets) and international trade markets. Investor behavior represents a further repercussion of the political origin of contagion.

Theories of contagion tend to be categorized as crisis-contingent and non-crisis-contingent. ${ }^{6}$ The former are theories that focus on showing why transmission mechanisms are altered during a crisis period, hence focusing on the reason for the increase in cross-market linkages after a shock. On the other hand, non-crisis-contingent theories assume that pre- and post-crisis transmission mechanisms are the same, thus assuming that cross-market links do not increase after a shock. ${ }^{7}$ Trade linkages are discussed in many studies, such as Forbes (2002), Hashimoto (2002) and Eichengreen et al. (1996). These studies generally find robust evidence that trade and competition in third markets are essential in the determination of financial contagion. ${ }^{8}$

Relatively few results are widely accepted in the financial literature on contagion. Most notably, contagion is more likely to be a regional rather than global phenomenon and is most likely to be driven by trade links rather than macroeconomic conditions (Eichengreen et al., 1996). Noteworthy empirical work on financial contagion includes King and Wadhwani (1990). Lee and Kim (1993) provide the results from the emerging market perspective. Importantly, more recent studies are less likely to find evidence of contagion as they take into account the role of the dynamic volatility bias (Forbes and Rigobon, 2002). For example, Dimitriou et al. (2014) find that emerging markets

\footnotetext{
${ }^{6}$ A collection of studies on contagion can be found in Claessens and Forbes (2001) and the surveys in Moser (2003) and Forbes (2004).

A review of the theories of how shocks are propagated internationally can be found in Claessens et al. (2001) and Dornbusch et al. (2000).

${ }^{7}$ For a discussion of financial linkages, see Goldfajn and Valdés (1997) and Van Rijckeghem and Weder (2001).

${ }^{8}$ See, for example, Corsetti et al. (2000), Gerlach and Smets (1995), Glick and Rose (1999) and Forbes (2002).
} 
were the most affected during the U.S. subprime crisis and provide evidence of the absence of contagious effects in the BRICS countries, which rather exhibited signs of decoupling. On the contrary, Celik (2012) documents contagious effects for most developed and emerging countries in the wake of the recent global financial crisis.

\section{Data and descriptive statistics}

In this paper, we use the stock market indices provided by Morgan Stanley Capital International Inc. (MSCI) ${ }^{9}$. We construct daily continuously compounded return series based on the total return indices, which account for reinvested dividends. Our main results are based on the US dollar returns to adopt the perspective of an international investor. We also check the robustness of our results by using local currency returns. ${ }^{10}$

We selected 19 stock market indices for the period November 30, 2007 - April 15, 2015. They include eight emerging markets - Brazil, China, Czech Republic, Hungary, India, Poland, Russia and Turkey; five frontier markets - Bulgaria, Estonia, Kazakhstan, Ukraine and Romania; and six developed markets - France, Germany, The Netherlands, United Kingdom, Japan and the United States. We also use data on the MSCI World Index (used as a market benchmark) and The MSCI Emerging and Frontier Markets (EFM) Index. ${ }^{11}$ We use this selection of world markets to provide an adequate balance between countries with high and low economic ties to Russia.

The pre-crisis period is originally defined as the period 1 January 2013 - 28 February 2014, whereas the crisis is the period March 1, 2014 - April 15, 2015. To ensure results robustness, we shift the two time periods in a variety of ways, in addition to employing a plethora of specifications, as described in Section 5. In order to further strengthen our results, we report our main results in Section 6, where the pre-crisis period is defined as 1 January 2013 - 28 February 2014 and the crisis period as March 1, 2014 - April 15, 2015. In fact, the consideration of the pre-crisis period as including the 2008 financial crisis, where correlations were generally very low among countries, should provide evidence of contagion most easily with regards to our crisis period. However, we show that this is not true, whereby decoupling from Russia represents a generally strong result during the Ukrainian crisis. Moreover, the original selection of the pre-crisis period allows for market stabilizations after the 2008 global financial crisis.

Summary statistics for the pre-crisis and the crisis periods are reported in Tables 1 and 2, respectively. The descriptive statistics show the first two moments of the returns distribution, as well

${ }^{9} \mathrm{MSCl}$ is a leading provider of equity, fixed income, and hedge fund indices. MSCl's equity indices have become the most widely used international equity benchmarks by institutional investors. MSCl's methodology ensures that the equity index series properly represent the markets and reflect their benchmark character.

10 Various other data and model specifications are used in this study to tackle the issue of robustness. These are explored in section 5.

11 The MSCI World Index captures large and mid-cap representation across 23 Developed Markets (DM) countries. With 1,643 constituents, the index covers approximately $85 \%$ of the free float-adjusted market capitalization in each country. The MSCI Emerging and Frontier Markets (EFM) Index captures large and mid-cap representation across 23 Emerging Markets (EM) countries and 23 Frontier Markets (FM) countries. With 959 constituents, the index covers approximately $85 \%$ of the free float-adjusted market capitalization in each country. 
as minimum and maximum values, measures of skewness and kurtosis, as well as the Jarque-Bera tests for normality of distributions and Augmented Dickey-Fuller unit root tests ${ }^{12}$.

\begin{tabular}{|c|c|c|c|c|c|c|c|c|}
\hline Index & Mean & Std. dev. & Min. & Max. & Skewness & Kurtosis & JB & ADF \\
\hline BRA & 0.0000715 & 0.0242 & -0.167 & 0.181 & 0.115 & 13.079 & $<0.0001$ & -16.596 \\
\hline BUL & -0.000703 & 0.0202 & -0.167 & 0.121 & -0.969 & 12.015 & $<0.0001$ & -17.998 \\
\hline CHN & 0.0000837 & 0.0201 & -0.1205 & 0.151 & 0.318 & 10.547 & $<0.0001$ & -17.057 \\
\hline CZC & -0.0000351 & 0.0213 & -0.154 & 0.218 & 0.358 & 16.505 & $<0.0001$ & -15.929 \\
\hline EST & 0.000127 & 0.0201 & -0.0889 & 0.134 & 0.386 & 7.208 & $<0.0001$ & -13.908 \\
\hline HUN & -0.000143 & 0.0285 & -0.184 & 0.225 & 0.409 & 9.738 & $<0.0001$ & -14.289 \\
\hline IND & 0.0000402 & 0.0203 & -0.113 & 0.215 & 0.554 & 13.143 & $<0.0001$ & -15.435 \\
\hline KZK & 0.0000248 & 0.0228 & -0.134 & 0.149 & 0.148 & 10.976 & $<0.0001$ & -16.506 \\
\hline POL & 0.000130 & 0.0240 & -0.125 & 0.153 & -0.013 & 7.045 & $<0.0001$ & -15.339 \\
\hline ROM & -0.0000524 & 0.0237 & -0.271 & 0.134 & -0.947 & 16.373 & $<0.0001$ & -16.307 \\
\hline RUS & -0.0000496 & 0.0273 & -0.226 & 0.271 & .270 & 19.078 & $<0.0001$ & -14.583 \\
\hline TUR & 0.0000159 & 0.0243 & -0.137 & 0.175 & 0.074 & 8.007 & $<0.0001$ & -15.048 \\
\hline UKR & -0.00122 & 0.0252 & -0.163 & 0.259 & 0.920 & 19.322 & $<0.0001$ & -16.842 \\
\hline FRA & 0.000171 & 0.0201 & -0.109 & 0.127 & 0.266 & 8.296 & $<0.0001$ & -18.371 \\
\hline GER & 0.000225 & 0.0194 & -0.0919 & 0.123 & 0.190 & 7.850 & $<0.0001$ & -17.458 \\
\hline JAP & 0.0000897 & 0.0156 & -0.0907 & 0.122 & -0.013 & 8.573 & $<0.0001$ & -19.223 \\
\hline NED & 0.000192 & 0.0184 & -0.108 & 0.111 & 0.126 & 8.617 & $<0.0001$ & -17.926 \\
\hline UK & 0.000228 & 0.0173 & -0.0991 & 0.130 & 0.185 & 10.996 & $<0.0001$ & -17.986 \\
\hline US & 0.000364 & 0.0149 & -0.0907 & 0.117 & -0.069 & 11.929 & $<0.0001$ & -19.604 \\
\hline EM/FM & 0.0000586 & 0.0145 & -0.0944 & 0.0999 & -0.210 & 10.440 & $<0.0001$ & -13.333 \\
\hline WLD & 0.000215 & 0.0126 & -0.0701 & 0.0902 & -0.276 & 9.699 & $<0.0001$ & -14.630 \\
\hline
\end{tabular}

Table 1 Descriptive statistics: Index returns in the pre-crisis period. The 1\%, 5\% and 10\% critical values for the ADF test are $-3.457,-2.878$ and -2.570 , respectively.

\begin{tabular}{|c|c|c|c|c|c|c|c|c|}
\hline Index & Mean & Std. dev. & Min. & Max. & Skewness & Kurtosis & JB & ADF \\
\hline BRA & -0.0000551 & 0.0219 & -0.0608 & 0.0836 & 0.265 & 4.262 & 0.0028 & -17.509 \\
\hline BUL & -0.00177 & 0.0139 & -0.0522 & 0.0542 & 0.071 & 4.853 & 0.0011 & -19.405 \\
\hline CHN & 0.00132 & 0.0107 & -0.0341 & 0.0602 & 0.565 & 6.570 & $<0.0001$ & -16.550 \\
\hline CZC & -0.000169 & 0.0107 & -0.0322 & 0.0301 & -0.041 & 3.078 & 0.8564 & -16.506 \\
\hline EST & -0.000912 & 0.0106 & -0.0384 & 0.0362 & 0.004 & 4.511 & 0.0042 & -16.488 \\
\hline HUN & 0.000439 & 0.0159 & -0.0641 & 0.0553 & 0.379 & 4.713 & 0.0001 & -14.786 \\
\hline IND & 0.00111 & 0.00957 & -0.0339 & 0.0272 & -0.342 & 3.907 & 0.0045 & -14.115 \\
\hline KZK & -0.000326 & 0.0214 & -0.0994 & 0.0839 & -0.202 & 6.141 & $<0.0001$ & -15.918 \\
\hline POL & -0.00041 & 0.0107 & -0.0604 & 0.0311 & -0.465 & 6.483 & $<0.0001$ & -15.676 \\
\hline ROM & 0.0000941 & 0.0103 & -0.0333 & 0.0312 & 0.195 & 4.001 & 0.0138 & -16.797 \\
\hline RUS & 0.000217 & 0.0245 & -0.122 & 0.145 & 0.388 & 9.646 & $<0.0001$ & -15.307 \\
\hline TUR & 0.000554 & 0.0174 & -0.0514 & 0.0666 & 0.001 & 3.578 & 0.1760 & -16.368 \\
\hline UKR & -0.00014 & 0.0399 & -0.294 & 0.237 & -0.317 & 20.526 & $<0.0001$ & -20.493 \\
\hline FRA & 0.00000263 & 0.00953 & -0.0386 & 0.0333 & -0.083 & 4.303 & 0.0080 & -18.763 \\
\hline GER & 0.000115 & 0.0101 & -0.0358 & 0.0318 & 0.080 & 3.892 & 0.0399 & -19.194 \\
\hline JAP & 0.0005528 & 0.00974 & -0.0268 & 0.0380 & 0.160 & 4.264 & 0.0065 & -20.823 \\
\hline NED & 0.000323 & 0.00894 & -0.0321 & 0.0292 & -0.062 & 4.211 & 0.0122 & -18.012 \\
\hline UK & -0.00000395 & 0.00823 & -0.0295 & 0.0314 & -0.267 & 5.999 & 0.0002 & -16.041 \\
\hline US & 0.000555 & 0.00723 & -0.0209 & 0.0241 & -0.193 & 3.793 & 0.0310 & -17.578 \\
\hline EM/FM & 0.000423 & 0.00687 & -0.0194 & 0.0192 & -0.066 & 3.043 & 0.8388 & -12.771 \\
\hline WLD & 0.000356 & 0.00563 & -0.0180 & 0.0192 & -0.139 & 3.921 & 0.0272 & -14.157 \\
\hline
\end{tabular}

Table 2 Descriptive statistics: stock index returns in the crisis period. The $1 \%, 5 \%$ and $10 \%$ critical values for the ADF test are $-3.457,-2.878$ and -2.570 , respectively.

\footnotetext{
${ }^{12}$ Appendix Figs. A1-A4 show the index returns series for each of the studied markets.
} 
Daily mean returns did not decrease in the crisis period compared to the pre-crisis period, as could be expected during a crisis (e.g. Chiang et al., 2007). Instead, returns increased in roughly half of the considered markets. Moreover, the variance of returns rose in virtually all markets. The volatility of returns increased on average by $54 \%$ in the crisis period compared to the pre-crisis period. In addition, stock returns minima and maxima rose in nearly all markets. The skewness of stock returns increased in the crisis period in $71 \%$ of cases, implying an increased frequency of negative returns. Finally, kurtosis increased in the crisis period in essentially all cases, with an average increase of ca. $51 \%$. This implies that the probability of large positive or negative shocks increased during the crisis period. Figures 1-3 illustrate the evolution of daily stock returns in the Russian stock market in comparison to a number of developed, emerging, and frontier markets before and during the Ukrainian crisis. A simple observation does reveal a significant plunge of the Russian market in the crisis period and the resulting changes in the co-movement pattern with other markets.
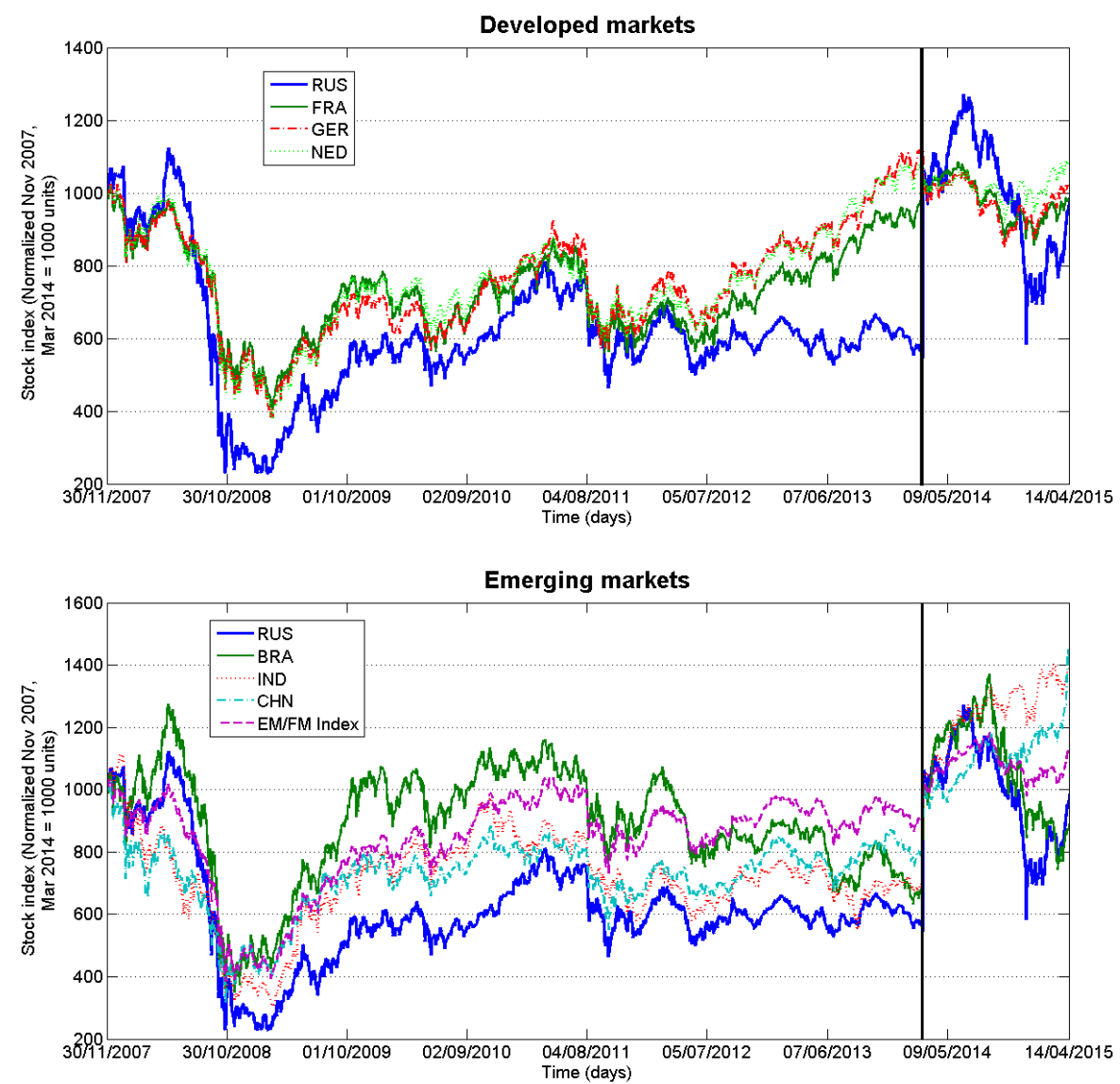


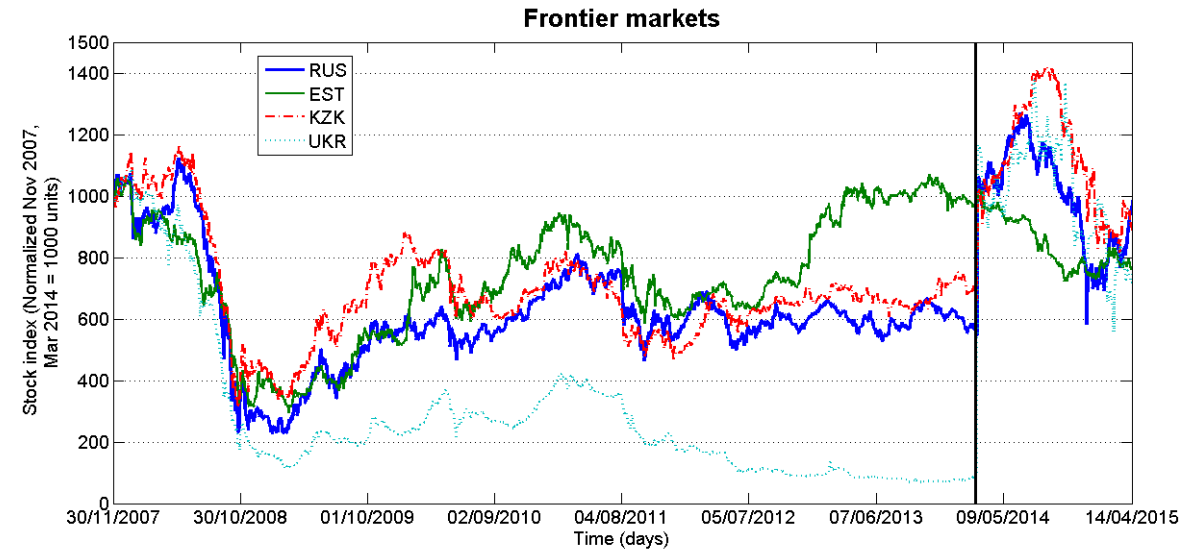

Fig. 1 (upper panel) - Daily returns on the MSCI Russia, the MSCI France, the MSCI Germany, and the MSCI Netherlands in the period November 2007-April 2015. In Figs.1-3, the two base dates for the indices are November 1, 2007 and March 1, 2014. The vertical line indicates the beginning of the Ukrainian crisis (March 1, 2014); Fig. 2 (middle panel) - Daily returns on the MSCI Russia, The MSCI France, the MSCI Brazil; Fig. 3 (lower panel) - Daily returns on the MSCI Russia, the MSCI Estonia, the MSCI Kazakhstan and the MSCI Ukraine in the period November 2007-April 2015.

5 Methodology

Forbes and Rigobon (2002) show how tests of financial contagion based on correlation coefficients are biased by heteroskedasticity. We use the dynamic conditional correlation (DCC) and the varying conditional correlation (VCC) AR-GARCH models, which estimate the correlation coefficients of the standardized residuals, thereby accounting for heteroskedasticity directly. The DCC-GARCH model continuously and efficiently adjusts the correlation in relation to the time-varying volatility thus providing a superior measure for dynamic cross-market correlation compared to other empirical models used to test for contagion (Cho and Parhizgari, 2008). An additional advantage of our approach is the multivariate nature of our model which enables us to measure the change in correlation, between the pre- and post-crisis periods, of a specific risk factor - in our case, the possible source of contagion, i.e. the Russian economic downfall - whilst accounting for systematic risk factor, represented in our case by the MSCI World Index. As opposed to other models such as the VEC and BEKK models (Engle and Kroner, 1995), our model enables the analysis of multiple asset returns simultaneously whilst maintaining a parsimonious setting (Chiang et al., 2007). MGARCH models mainly differ in the flexibility and parsimony of their specifications for a timevarying conditional covariance matrix of the disturbances, designated $\mathrm{H}_{\mathrm{t}}$. Such models treat the diagonal elements of $\mathrm{H}_{\mathrm{t}}$ as univariate $\mathrm{GARCH}$ models while the off-diagonal entries are represented by nonlinear functions of the diagonal terms.

The multivariate DCC-GARCH model is specified as:

$$
h_{i j, t}=\rho_{i j, t} \sqrt{h_{i i, t} h_{j j, t}}
$$

where the elements on the main diagonal $\left(h_{i i, t}\right.$ and $\left.h_{j j, t}\right)$ follow univariate GARCH processes and the time-varying correlation coefficient $\rho_{i j, t}$ follows the dynamic process discussed in Engle (2002) and presented below. The daily mean stock return generating process for market $\mathrm{A}, r_{t}^{A}$, in relation to each of the 19 international equity markets under analysis, is described by: 


$$
r_{t}^{A}=\omega_{0}+\omega_{1} r_{t-1}^{A}+\omega_{2} r_{t-1}^{R U S}+\omega_{3} r_{t-1}^{W L D}+\varepsilon_{t}
$$

where $r_{t}^{A}$ is a vector of dependent variables, $r_{t-1}^{R U S}$ is the one-period lagged return from the Russian index accounting for idiosyncratic risk and the source of contagion, $r_{t-1}^{W L D}$ represents the systematic risk component, $r_{t-1}^{A}$ is an $\mathrm{AR}(1)$ term used to account for autocorrelation in stock returns, and $\omega_{0}, \omega_{1-3}$ are the model intercept and unconditional cross-market correlation coefficients to be estimated, respectively. More formally, Eq.2 can be expressed in matrix form as $r_{t}^{A}=C x_{t}+\varepsilon_{t}$, where $\mathrm{C}$ is a matrix of parameters, $x_{t}$ is a vector of independent variables, which contains one lag of $r_{t}^{A}$ in addition to the specific and market risk factors. The contemporary disturbances, $\varepsilon_{t}$, are expressed as: $\varepsilon_{t}=H_{t}{ }^{1 / 2} v_{t}$, where $\varepsilon_{t} \mid \varphi_{t-1} \sim N\left(0, H_{t}\right)$ and $v_{t}$ is an $m x 1$ vector of normal, independent and identically distributed innovations.

The multiplicative heteroskedasticity of returns is defined as:

$$
H_{t}=D_{t}{ }^{1 / 2} R_{t} D_{t}{ }^{1 / 2}
$$

where $H_{t}{ }^{1 / 2}$ is the Cholesky factor of the time-varying conditional covariance matrix $H_{t}$, and $R$ is a correlation matrix holding the conditional correlations. We define $D_{t}$ as:

$$
D_{t}=\left\{\operatorname{diag}\left(\sqrt{h_{i, t}}\right)\right\}=\left(\begin{array}{cccc}
\sigma_{1, t}^{2} & 0 & \cdots & 0 \\
0 & \sigma_{2, t}^{2} & \cdots & 0 \\
\vdots & \vdots & \ddots & \vdots \\
0 & 0 & \cdots & \sigma_{m, t}^{2}
\end{array}\right)
$$

in which $\sigma_{i, t}^{2}$ evolves as a univariate GARCH model of the form:

$$
\sigma_{n, t}^{2}=\exp \left(\gamma_{i} z_{i, t}\right)+\delta_{1}^{R U S} \sigma_{1, t-1}^{2}+\delta_{2}^{W L D} \sigma_{2, t-1}^{2}+\sum_{j=1}^{p_{i}} \alpha_{j} \varepsilon_{i, t-j}^{2}+\sum_{j=1}^{q_{i}} \beta_{j} \sigma_{i, t-j}^{2}
$$

where the variance of stock returns is dependent on the Russian one-period lagged return variance and the world index lagged return, in the basic mode ${ }^{13}$. More specifically, $\sigma_{n, t}^{2}$ is the present variance of a single stock return (where $n=1 \ldots 19), \gamma_{i}(t)$ is a $1 x p$ vector of parameters, $z_{i, t}$ is a $p x 1$ vector of independent variables, including a constant term, the $\alpha_{j}$ 's represent ARCH parameters and the $\beta_{j}$ 's are GARCH parameters.

The matrix of conditional quasicorrelations introduced in Eq. 3 is given by:

$$
R_{t}=\operatorname{diag}\left(Q_{t}\right)^{-1 / 2} Q \operatorname{diag}\left(Q_{t}\right)^{-1 / 2}=\left(\begin{array}{cccc}
1 & \rho_{12, t} & \cdots & \rho_{1 m, t} \\
\rho_{12, t} & 1 & \cdots & \rho_{2 m, t} \\
\vdots & \vdots & \ddots & \vdots \\
\rho_{1 m, t} & 0 & \cdots & 1
\end{array}\right)
$$

In the case in which non-concave or discontinuous regions of likelihood functions are met in the estimation of the multiplicative heteroskedasticity, we estimate the following equation (i.e., without exogenous variables in Eq. 5), ensuring differentiability. Although this process may worsen the specification of our model it improves parsimony:

$$
\sigma_{1, t}^{2}=c_{i}+\sum_{j=1}^{p_{i}} \alpha_{j} \varepsilon_{i, t-j}^{2}+\sum_{j=1}^{q_{i}} \beta_{j} \sigma_{i, t-j}^{2}
$$

\footnotetext{
${ }^{13}$ We also use interest and exchange rates in other specifications of both the returns and their multiplicative heeroscedasticity, yielding consistent results. Due to space constraints, this study only reports the results obtained throughout the basic model, explained through Eq. 1-10; Results relating to similar models employed in the study can be made available upon request.
} 
where $p$ and $q$ represent the order of the AR-GARCH $(1,1)$ model, ascertained using AIC and BIC. In Eq. $7, Q_{t}$ is specified as follows:

$$
Q_{t}=\left(1-\lambda_{1}-\lambda_{2}\right) R+\lambda_{1} \tilde{\varepsilon}_{t-1} \tilde{\varepsilon}_{t-1}+\lambda_{2} Q_{t-1}
$$

where $\tilde{\varepsilon}_{t}$ is a vector of standardized residuals, $D_{t}{ }^{-1 / 2} \varepsilon_{t}$ and $\lambda_{1}$ and $\lambda_{2}$ are parameters governing the dynamics of the conditional quasicorrelations; $\lambda_{1}$ and $\lambda_{2}$ are non-negative and satisfy $0 \leq \lambda_{1}+\lambda_{1}<1$ in a stable solution.

When $Q_{t-1}$ is verified as stationary, the matrix $R$ in (7) becomes a weighted average of the unconditional covariance matrix $\left(\bar{R}_{t}\right)$ of the standardized residuals, $\tilde{\varepsilon}_{t}$, and the unconditional mean of $Q_{t}$, i.e. $\bar{Q}_{t}$. Given that $\bar{R} \neq \bar{Q}$, it is safe to state that $\mathrm{R}$ neither represents the unconditional correlation matrix, nor the unconditional mean of $Q_{t}$, thus we can identify them as quasicorrelations, these being crucial toward the estimation of our model.

The various DCC MGARCH models for each market, using subsamples relating to the preand post-crisis periods, are then estimated by maximum likelihood. Because the $v_{t}$ 's are assumed to follow a multivariate t-distribution with more than two degrees of freedom (df), the log-likelihood function for the $t^{\text {th }}$ observation is given by:

$$
\begin{aligned}
l_{t}= & \log \Gamma\left(\frac{d f+m}{2}\right)-\log \Gamma\left(\frac{d f}{2}\right)-\frac{m}{2} \log \{(d f-2) \pi\} \\
& -0.5 \log \left\{\operatorname{det}\left(R_{t}\right)\right\}-\log \left\{\operatorname{det}\left(D_{t^{\frac{1}{2}}}^{\frac{1}{2}}\right)\right\}-\frac{d f+m}{2} \log \left(1+\frac{\tilde{\varepsilon}_{t} R_{t}{ }^{-1} \tilde{\varepsilon}_{t}{ }^{\prime}}{d f-2}\right)
\end{aligned}
$$

We perform the first optimization step in the unconstrained space. Once a maximum is found, we impose the constraints $\lambda_{1} \geq 0, \lambda_{2} \geq 0$, and $0 \leq \lambda_{1}+\lambda_{1}<1$, as before, to then maximize the loglikelihood in the constrained space. Our estimation method requires initial values that can be plugged in for $\varepsilon_{t-i} \varepsilon_{t-i}{ }^{\prime}$ and $\mathrm{H}_{t-j}$ when $t-i<1$ and $t-j<1$, thus we substitute an estimator of the unconditional covariance of the disturbances:

$$
\widehat{\Sigma}=\mathrm{T}^{-1} \sum_{t=1}^{T} \hat{\varepsilon}_{t} \hat{\varepsilon}_{t}{ }^{\prime}
$$

for $\varepsilon_{t-i} \varepsilon_{t-i}{ }^{\prime}$ when $t-i<1$ and for $\mathrm{H}_{t-j}$ when $t-j<1$, where $\hat{\varepsilon}_{t}$ represents the vector of residuals previously calculated using the estimated parameters.

We also test for robustness of our results by employing a variety of model and data specifications. Relating to the former, we use: the simplest $\operatorname{AR}(1)-\mathrm{GARCH}(1,1)$ model of Bollerslev (1990), the asymmetric GARCH model - used to account for the possibility of asymmetric innovations - and the VCC MGARCH model by Tse and Tsui (2002), in which the conditional correlations at each period are given by a weighted sum of a time-invariant component, a measure of recent correlations among the residuals, and the last period's conditional correlations. In order to ensure parsimony, we impose a restriction on the conditional correlations to follow the same dynamics. Furthermore, the asymmetric GARCH model specifies the simple asymmetric ARCH terms. By adding these terms we are making the standard $\mathrm{GARCH}$ model respond asymmetrically to positive and negative innovations. 
On the other hand, we also employ a series of data specifications to confirm the robustness of our results. These include using interest and exchange rates, oil prices and volume of trading in both the mean and variance equations as control variables. In addition, we employ variables defined as local returns, 6-monthly rolling average returns and weekly returns. We also employ zero, one or five lags to describe the mean and variance of stock returns. We additionally study equal time lengths for the pre-crisis and the crisis period and also shift such periods by one month in both directions until the periods may not provide equal number of observations.

We derive the coefficient of dynamic correlation, $\omega_{2}$, attached to the Russian stock return, $r_{t-1}^{R U S}$, from the DCC model and test, via the Fisher Z-transformation, whether a statistically significant change occurred in the coefficient after the crisis period. The correlation coefficient $\omega_{2}$, expressed in terms of country $i$, (the affected market) and country $j$ (the source of contagion, in our case the Russian market) is given by:

$$
\omega_{i j, t}=\frac{\left(1-\lambda_{1}-\lambda_{2}\right) \bar{h}_{i j}+\lambda_{1} \varepsilon_{i, t-1} \varepsilon_{j, t-1}+\lambda_{2} \bar{h}_{i j, t-1}}{\left[\left(1-\lambda_{1}-\lambda_{2}\right) \bar{h}_{i i}+\lambda_{1} \varepsilon_{i, t-1}^{2}+\lambda_{2} h_{i i, t-1}\right]^{0.5}\left[\left(1-\lambda_{1}-\lambda_{2}\right) \bar{h}_{j j}+\lambda_{1} \varepsilon_{j, t-1}^{2}+\lambda_{2} h_{j j, t-1}\right]^{0.5}} .
$$

Where all parameters are specified throughout Eq. 1-10 and we refer to the DCC-MGARCH mean model specified in Eq.2. The t-statistics on the coefficient $\omega_{i j, t}$ is used to find the degree of correlation for each market. The null and alternative hypotheses are defined as:

$$
H_{0}=\omega_{\text {turmoil }}^{\text {RUS }}=\omega_{\text {stable }}^{\text {RUS }} ; H_{1}=\omega_{\text {turmoil }}^{\text {RUS }} \neq \omega_{\text {stable }}^{\text {RUS }}
$$

where $\omega_{\text {turmoil }}^{\text {RUS }}$ and $\omega_{\text {stable }}^{\text {RUS }}$ are the dynamic correlation coefficients observed in the two periods. Assuming independence between the sample coefficients, we test for the difference in correlation over the two periods. This requires the computation of Fisher's transform, a variance-stabilizing transformation of the correlation coefficient between the market return in question and the explanatory return when the two time series follow a bivariate normal distribution. We first convert each coefficient into a $z$-score using an inverse hyperbolic tangent and derive $z$ as:

$$
z=0.5 \ln \frac{1+\omega_{\text {turmoil }}^{\text {RUS }}}{1-\omega_{\text {turmoil }}^{\text {UUS }}}=\operatorname{arctanh}\left(\omega_{\text {turmoil }}^{\text {RUS }}\right) \text {. }
$$

We then consider the sample sizes for each period, $n^{\text {turmoil }}$ and $n^{\text {stable }}$, to compare the obtained zscores:

$$
z=\frac{z_{\text {turmoil }}-z_{\text {stable }}}{\left[\left(n_{\text {turmoil }}-3\right)+\left(n_{\text {stable }}-3\right)\right]^{0.5}} .
$$

If $z>1.65$, then $p<0.05$, indicating a significant change in the correlation coefficient from the stable to the turmoil period. In these cases, we derive the rates of change $\Delta_{A, R}=\left(\omega_{\text {turmoil }}^{R U S}-\right.$ $\left.\omega_{\text {stable }}^{R U S}\right) / \omega_{\text {stable }}^{R U S}$, where financial contagion from Russia to country A is defined as $\Delta_{A, R}>0$. If $\Delta_{A, R}<$ 0 , we acknowledge evidence of decoupling, signaling the falling influence of the Russian equity market, whereas if $\Delta_{A, R}=0$, the degree of correlation between Russia and country $A$ is stationary. It is reasonable to hypothesize that during any turmoil period or crisis, correlations are expected to increase (Dimson et al., 2014). 


\section{Results}

Our use of the DCC-MGARCH model enabled us to dynamically control for volatility biases. The following tables report the results of this analysis. The unconditional correlations, before and during the crisis period, relate daily returns of the $\mathrm{MSCl}$ Russia Index with those observed in the developed Western markets (Table 3), the major Asian equity markets (Table 4), the emerging markets (Table 5) and the frontier markets (Table 6).

\begin{tabular}{|c|c|c|c|c|c|c|c|c|c|c|}
\hline \multirow{2}{*}{$\begin{array}{c}\text { Developed } \\
\text { markets }\end{array}$} & \multicolumn{2}{|c|}{ FRA } & \multicolumn{2}{|c|}{ GER } & \multicolumn{2}{|c|}{ NED } & \multicolumn{2}{|c|}{ UK } & \multicolumn{2}{|c|}{ USA } \\
\hline & Pre-crisis & Crisis & Pre-crisis & Crisis & Pre-crisis & Crisis & Pre-crisis & Crisis & Pre-crisis & Crisis \\
\hline \multicolumn{11}{|c|}{ Mean model } \\
\hline RUSSIA & $\begin{array}{l}0.124^{\star \star *} \\
(0.0134) \\
P<0.0001\end{array}$ & $\begin{array}{c}-0.0304^{* *} \\
(0.0155) \\
P=0.049\end{array}$ & $\begin{array}{c}0.146^{\star * *} \\
(0.0133) \\
P<0.0001\end{array}$ & $\begin{array}{c}-0.0304^{\star *} \\
(0.0155) \\
P=0.049\end{array}$ & $\begin{array}{c}0.110^{\star \star \star} \\
(0.0138) \\
P<0.0001\end{array}$ & $\begin{array}{l}0.00866 \\
(0.0186) \\
P=0.641\end{array}$ & $\begin{array}{c}0.118^{\star * *} \\
(0.0115) \\
P<0.0001\end{array}$ & $\begin{array}{l}0.00507 \\
(0.0145) \\
P=0.727\end{array}$ & $\begin{array}{c}0.133^{\star \star *} \\
(0.0087) \\
P<0.0001\end{array}$ & $\begin{array}{c}-0.0219^{\star \star *} \\
(0.0841) \\
\mathrm{P}=0.009\end{array}$ \\
\hline WORLD & $\begin{array}{c}1.264^{\star * *} \\
(0.0303) \\
P<0.0001\end{array}$ & $\begin{array}{c}1.336^{\star * *} \\
(0.0747) \\
P<0.0001\end{array}$ & $\begin{array}{c}1.161^{* * *} \\
(0.0282) \\
\mathrm{P}<0.0001\end{array}$ & $\begin{array}{c}1.336^{* \star *} \\
(0.0747) \\
P<0.0001\end{array}$ & $\begin{array}{c}1.127^{\star \star *} \\
(0.0289) \\
P<0.0001\end{array}$ & $\begin{array}{c}1.1099^{\star * *} \\
(0.0747) \\
P<0.0001\end{array}$ & $\begin{array}{c}1.016^{\star * *} \\
(0.0248) \\
P<0.0001\end{array}$ & $\begin{array}{c}1.0387^{\star * *} \\
(0.0652) \\
P<0.0001\end{array}$ & $\begin{array}{c}1.148^{\star \star *} \\
(0.0186) \\
P<0.0001\end{array}$ & $\begin{array}{c}1.149^{\star * *} \\
(0.0386) \\
P<0.0001\end{array}$ \\
\hline Constant & $\begin{array}{c}-0.000269 \\
(0.000199) \\
P=0.176\end{array}$ & $\begin{array}{c}-0.000451 \\
(0.000311) \\
P=0.148\end{array}$ & $\begin{array}{c}-0.000054 \\
(0.000193) \\
P=0.778\end{array}$ & $\begin{array}{c}-0.00045 \\
(0.00031) \\
P=0.148\end{array}$ & $\begin{array}{c}-0.000051 \\
(0.000196) \\
P=0.799\end{array}$ & $\begin{array}{c}-0.000064 \\
(0.000307) \\
P=0.834\end{array}$ & $\begin{array}{c}-0.00013 \\
(0.00016) \\
P=0.394\end{array}$ & $\begin{array}{c}-0.00038 \\
(0.00028) \\
P=0.169\end{array}$ & $\begin{array}{c}0.000052 \\
(0.00011) \\
P=0.649\end{array}$ & $\begin{array}{c}0.0001704 \\
(0.000162) \\
P=0.292\end{array}$ \\
\hline \multicolumn{11}{|c|}{ Multiplicative heteroskedasticity model } \\
\hline arch & $\begin{array}{l}0.05005^{\star \star} \\
(0.02006) \\
P=0.014\end{array}$ & $\begin{array}{c}0.1805^{\star \star \star} \\
(0.0696) \\
P=0.010\end{array}$ & $\begin{array}{c}0.0679^{\star \star *} \\
(0.0111) \\
P<0.0001\end{array}$ & $\begin{array}{c}0.1805^{\star \star \star} \\
(0.0696) \\
P=0.010\end{array}$ & $\begin{array}{c}0.0509^{\star \star \star} \\
(0.0104) \\
P<0.0001\end{array}$ & $\begin{array}{l}0.134^{\star \star \star} \\
(0.0475) \\
P=0.005\end{array}$ & $\begin{array}{c}0.0636^{\star \star \star} \\
(0.0157) \\
P<0.0001\end{array}$ & $\begin{array}{c}0.143^{\star \star \star} \\
(0.0441) \\
P<0.0001\end{array}$ & $\begin{array}{c}0.071^{\star \star \star} \\
(0.0157) \\
P<0.0001\end{array}$ & $\begin{array}{c}0.244^{\star *} \\
(0.986) \\
P=0.013\end{array}$ \\
\hline garch & $\begin{array}{c}0.836^{* * *} \\
(0.0366) \\
P<0.0001 \\
\end{array}$ & $\begin{array}{l}0.712^{\star \star *} \\
(0.1015) \\
\mathrm{P}<0.0001\end{array}$ & $\begin{array}{c}0.918^{\star \star \star} \\
(0.0128) \\
P<0.0001\end{array}$ & $\begin{array}{c}0.712^{\star \star *} \\
(0.102) \\
P<0.0001 \\
\end{array}$ & $\begin{array}{c}0.925^{\star \star \star} \\
(0.0126) \\
\mathrm{P}<0.0001\end{array}$ & $\begin{array}{c}0.844^{* * *} \\
(0.0498) \\
P<0.0001\end{array}$ & $\begin{array}{c}0.845^{\star \star \star} \\
(0.0267) \\
P<0.0001\end{array}$ & $\begin{array}{c}0.779^{\star \star *} \\
(0.0668) \\
P<0.0001\end{array}$ & $\begin{array}{c}0.854^{\star \star *} \\
(0.0239) \\
P<0.0001\end{array}$ & $\begin{array}{l}0.534^{\star \star} \\
(0.252) \\
P=0.034\end{array}$ \\
\hline RUSSIA & $\begin{array}{c}-1.368 \\
(4.304) \\
P=0.751\end{array}$ & & & & $\begin{array}{c}4.683 \\
(3.396) \\
P=0.168\end{array}$ & & $\begin{array}{c}-6.213 \\
(5.803) \\
P=0.230\end{array}$ & & $\begin{array}{c}-2.034 \\
(7.545) \\
P=0.787\end{array}$ & \\
\hline WORLD & $\begin{array}{c}-77.047^{\star \star \star} \\
(8.0566) \\
P<0.0001\end{array}$ & & & & $\begin{array}{c}69.717^{\star \star *} \\
(6.694) \\
P<0.0001\end{array}$ & & $\begin{array}{c}-76.068^{\star \star *} \\
(9.9602) \\
P<0.0001\end{array}$ & & $\begin{array}{c}-85.194^{\star \star \star} \\
(12.638) \\
P<0.0001\end{array}$ & \\
\hline Constant & $\begin{array}{c}-12.075^{\star * *} \\
(0.2138) \\
P<0.0001\end{array}$ & $\begin{array}{c}4.33 \mathrm{e}-6^{*} \\
(5.4 \mathrm{e}-6) \\
\mathrm{P}=0.088\end{array}$ & $\begin{array}{c}1.25 e-6^{\star * *} \\
(4.24 \mathrm{e}-7) \\
P=0.003\end{array}$ & $\begin{array}{c}4.33 e-6^{*} \\
(2.54 \text { e-6) } \\
P=0.088\end{array}$ & $\begin{array}{c}-13.609^{\star * *} \\
(0.308) \\
P<0.0001\end{array}$ & $\begin{array}{c}1.16 \mathrm{e}-6 \\
(8.67 \mathrm{e}-7) \\
\mathrm{P}=0.181\end{array}$ & $\begin{array}{c}-12.742^{\star * *} \\
(0.211) \\
P<0.0001\end{array}$ & $\begin{array}{c}2.49 e-6^{* *} \\
(1.27 \text { e-6) } \\
P=0.05\end{array}$ & $\begin{array}{c}-13.572^{* \star *} \\
(0.223) \\
P<0.0001\end{array}$ & $\begin{array}{c}2.34 \mathrm{e}-6 \\
(1.89 \mathrm{e}-6) \\
\mathrm{P}=0.216\end{array}$ \\
\hline \multicolumn{11}{|c|}{ Model diagnostics } \\
\hline arch+garch & & & & & & & & & & \\
\hline Wald $\chi^{2}$ & $\begin{array}{c}4034.03^{\star \star *} \\
P<0.0001\end{array}$ & $\begin{array}{l}400.67^{\star \star *} \\
P<0.0001\end{array}$ & $\begin{array}{c}4013.76^{\star \star \star} \\
P<0.0001\end{array}$ & $\begin{array}{l}400.67^{\star \star \star} \\
P<0.0001\end{array}$ & $\begin{array}{l}3618.35^{\star \star \star} \\
\mathrm{P}<0.0001\end{array}$ & $\begin{array}{l}294.50^{\star \star *} \\
P<0.0001\end{array}$ & $\begin{array}{l}4353.32^{\star \star \star} \\
P<0.0001\end{array}$ & $\begin{array}{l}324.97^{\star \star \star} \\
P<0.0001\end{array}$ & $\begin{array}{c}5348.77^{\star \star \star} \\
P<0.0001\end{array}$ & $\begin{array}{c}1079.97^{\star \star \star} \\
P<0.0001\end{array}$ \\
\hline LL & 5403.633 & 1080.660 & 5412.983 & 1080.66 & 5431.483 & 1086.311 & 5712.604 & 1120.686 & 6198.925 & 1277.759 \\
\hline AIC & -10791.27 & -2149.320 & -10813.97 & 2149.320 & -10846.97 & -2160.622 & -11409.21 & -2229.372 & -12381.85 & -2453.518 \\
\hline BIC & -10748.10 & -2127.259 & -10781.59 & $\begin{array}{c}- \\
2127.259\end{array}$ & -10803.80 & -2138.562 & -11366.04 & -2207.311 & -12338.68 & -2521.457 \\
\hline
\end{tabular}

Table 3 - Developed markets. Correlation of $\mathrm{MSCl}$ index returns for France, Germany, the Netherlands, the United Kingdom and the US with the MSCI Russia and the MSCI World, during the pre-crisis and the crisis periods. Dynamic conditional correlation $\mathrm{AR}(1)-\mathrm{MGARCH}(1,1)$ mean and variance model parameters and diagnostics are reported. Standard 
errors are given in brackets. The pre-crisis and the crisis periods are November 2007-February 2014 and March 2014 April 2015, respectively.

The results depicted in Table 3 show that the dynamic correlations between the Russian market and the developed markets significantly decreased in the crisis period, except for the Netherlands and the UK, where the decrease in correlation was insignificant. The drop in return correlations of the Russian market with the French, German, and the US markets was very large and ranged from 75.5 to $84 \%$. In fact, the correlations of the returns in these markets with the Russian market turned from positive to negative, potentially suggesting increased diversification possibilities. On the other hand, the source of market risk for each of the developed markets in our sample was significant both before and during the crisis. The correlation of the $\mathrm{MSCl}$ World Index returns with the developed markets increased in all cases during the crisis, except for the Netherlands; this correlation increased by $5.7 \%$ in France, $15.07 \%$ in Germany, $2.23 \%$ in the UK and $8.7 \%$ in the US.

\begin{tabular}{|c|c|c|c|c|c|c|c|c|}
\hline \multirow{2}{*}{$\begin{array}{c}\text { Other major } \\
\text { financial markets }\end{array}$} & \multicolumn{2}{|c|}{ IND } & \multicolumn{2}{|c|}{ CHN } & \multicolumn{2}{|c|}{ JAP } & \multicolumn{2}{|c|}{ EM/FM } \\
\hline & Pre-crisis & Crisis & Pre-crisis & Crisis & Pre-crisis & Crisis & Pre-crisis & Crisis \\
\hline \multicolumn{9}{|c|}{ Mean model } \\
\hline RUSSIA & $\begin{array}{c}0.164^{* \star *} \\
(0.032) \\
P<0.0001\end{array}$ & $\begin{array}{c}0.066^{* *} \\
(0.029) \\
P=0.025\end{array}$ & $\begin{array}{c}0.167^{* * *} \\
(0.031) \\
P<0.0001\end{array}$ & $\begin{array}{c}0.049^{\star} \\
(0.028) \\
P=0.080\end{array}$ & $\begin{array}{c}-0.028 \\
(0.023) \\
P=0.222\end{array}$ & $\begin{array}{c}0.0092 \\
(0.023) \\
P=0.685\end{array}$ & $\begin{array}{c}0.195^{\star * *} \\
(0.0122) \\
P<0.0001\end{array}$ & $\begin{array}{c}0.106^{* * *} \\
(0.0196) \\
P<0.0001\end{array}$ \\
\hline WORLD & $\begin{array}{c}0.547^{* * *} \\
(0.068) \\
P<0.0001\end{array}$ & $\begin{array}{c}0.387^{\star \star *} \\
(0.121) \\
P=0.001\end{array}$ & $\begin{array}{c}0.510^{* \star *} \\
(0.057) \\
P<0.0001\end{array}$ & $\begin{array}{c}0.497^{\star \star *} \\
(0.098) \\
P<0.0001\end{array}$ & $\begin{array}{c}0.428^{\star * *} \\
(0.046) \\
P<0.0001\end{array}$ & $\begin{array}{c}0.341^{\star * *} \\
(0.117) \\
P=0.004\end{array}$ & $\begin{array}{c}0.641^{* \star *} \\
(0.0242) \\
P<0.0001\end{array}$ & $\begin{array}{c}0.545^{\star \star *} \\
(0.083) \\
P<0.0001\end{array}$ \\
\hline Constant & $\begin{array}{l}-0.00011 \\
(0.00033) \\
P=0.727\end{array}$ & $\begin{array}{l}0.0011^{* *} \\
(0.00050) \\
P=0.022\end{array}$ & $\begin{array}{c}-0.000096 \\
(0.00031) \\
P=0.756\end{array}$ & $\begin{array}{c}0.00075 \\
(0.00055) \\
P=0.173\end{array}$ & $\begin{array}{c}0.00041 \\
(0.00028) \\
P=0.152\end{array}$ & $\begin{array}{c}0.00058 \\
(0.00045) \\
P=0.192\end{array}$ & $\begin{array}{l}-0.000049 \\
(0.00014) \\
P=0.732\end{array}$ & $\begin{array}{c}0.00027 \\
(0.00029) \\
P=0.345\end{array}$ \\
\hline \multicolumn{9}{|c|}{ Multiplicative heteroskedasticity model } \\
\hline arch & $\begin{array}{c}0.068^{\star * *} \\
(0.025) \\
P=0.007\end{array}$ & $\begin{array}{c}0.033^{\star * *} \\
(0.003) \\
P<0.0001\end{array}$ & $\begin{array}{c}0.0501^{\star * \star} \\
(0.014) \\
P<0.0001\end{array}$ & $\begin{array}{l}0.083^{\star \star \star} \\
(0.0298) \\
P=0.005\end{array}$ & $\begin{array}{c}0.089^{* \star \star} \\
(0.024) \\
P<0.0001\end{array}$ & $\begin{array}{l}0.059^{\star *} \\
(0.029) \\
P=0.044\end{array}$ & $\begin{array}{c}0.040^{\star \star *} \\
(0.010) \\
P<0.0001\end{array}$ & $\begin{array}{c}0.024^{\star \star \star} \\
(0.008) \\
P<0.0001\end{array}$ \\
\hline garch & $\begin{array}{l}0.925^{\star * *} \\
(0.0195) \\
P<0.0001\end{array}$ & $\begin{array}{c}0.760^{* * *} \\
(0.041) \\
P<0.0001\end{array}$ & $\begin{array}{c}0.922^{* * *} \\
(0.021) \\
P<0.0001\end{array}$ & $\begin{array}{c}0.816^{\star \star *} \\
(0.048) \\
P<0.0001\end{array}$ & $\begin{array}{c}0.832^{\star * *} \\
(0.046) \\
P<0.0001\end{array}$ & $\begin{array}{c}0.887^{\star * *} \\
(0.335) \\
P<0.0001\end{array}$ & $\begin{array}{c}0.917^{* \star *} \\
(0.021) \\
P<0.0001\end{array}$ & $\begin{array}{c}0.962^{* * *} \\
(0.31) \\
P=0.004\end{array}$ \\
\hline RUSSIA & $\begin{array}{c}3.433 \\
(5.039) \\
P=0.496 \\
\end{array}$ & $\begin{array}{c}33.747^{* * *} \\
(6.885) \\
\mathrm{P}<0.0001 \\
\end{array}$ & $\begin{array}{c}-9.655 \\
(6.135) \\
P=0.116 \\
\end{array}$ & $\begin{array}{c}16.687^{\star *} \\
(8.428) \\
\mathrm{P}=0.048 \\
\end{array}$ & $\begin{array}{l}16.054^{*} \\
(8.903) \\
\mathrm{P}=0.071\end{array}$ & $\begin{array}{l}19.759^{\star} \\
(11.001) \\
P=0.072\end{array}$ & $\begin{array}{c}-4.002 \\
(4.706) \\
P=0.393\end{array}$ & $\begin{array}{c}-5.781 \\
(6.885) \\
P=0.401 \\
\end{array}$ \\
\hline WORLD & $\begin{array}{c}69.699^{* * *} \\
(10.116) \\
P<0.0001\end{array}$ & $\begin{array}{c}-187.034^{\star * *} \\
(34.747) \\
P<0.0001\end{array}$ & $\begin{array}{l}-62.244^{* * *} \\
(13.663) \\
P<0.0001\end{array}$ & $\begin{array}{c}2.839 \\
(55.352) \\
P=0.959\end{array}$ & $\begin{array}{c}-87.557^{\star \star \star} \\
(10.377) \\
P<0.0001\end{array}$ & $\begin{array}{c}-274.412^{* * *} \\
(51.727) \\
P<0.0001\end{array}$ & $\begin{array}{c}-72.480^{* * *} \\
(9.412) \\
P<0.0001 \\
\end{array}$ & $\begin{array}{c}-158.147 \\
(156.899) \\
P=0.313\end{array}$ \\
\hline Constant & $\begin{array}{c}-13.299^{* * *} \\
(0.547) \\
P<0.0001\end{array}$ & $\begin{array}{c}-11.513^{* * *} \\
(0.362) \\
P<0.0001\end{array}$ & $\begin{array}{c}-12.541^{* * *} \\
(0.442) \\
P<0.0001\end{array}$ & $\begin{array}{c}-11.529^{* * *} \\
(0.491) \\
P<0.0001\end{array}$ & $\begin{array}{c}-11.518^{\star \star \star} \\
(0.403) \\
P<0.0001\end{array}$ & $\begin{array}{c}-13.441^{* * *} \\
(0.687) \\
P<0.0001\end{array}$ & $\begin{array}{c}-13.706^{* * *} \\
(0.351) \\
P<0.0001 \\
\end{array}$ & $\begin{array}{c}-14.0 .62^{* *} \\
(5.760) \\
P=0.015\end{array}$ \\
\hline \multicolumn{9}{|c|}{ Model diagnostics } \\
\hline arch+garch & 0.993 & 0.793 & 0.972 & 0.899 & 0.921 & 0.946 & 0.957 & 0.986 \\
\hline Wald $\chi^{2}$ & $\begin{array}{l}405.84^{\star \star *} \\
P<0.0001\end{array}$ & $\begin{array}{c}33.43^{\star \star \star} \\
P<0.0001\end{array}$ & $\begin{array}{l}401.26^{\star \star \star} \\
P<0.0001\end{array}$ & $\begin{array}{c}47.12^{\star \star *} \\
\mathrm{P}<0.0001\end{array}$ & $\begin{array}{l}146.23^{\star \star *} \\
P<0.0001\end{array}$ & $\begin{array}{c}12.90^{\star \star \star} \\
P=0.0016\end{array}$ & $\begin{array}{l}3044.67^{\star \star \star} \\
P<0.0001\end{array}$ & $\begin{array}{l}214.22^{\star * *} \\
P<0.0001\end{array}$ \\
\hline LL & 4493.73 & 978.274 & 4607.881 & 936.427 & 4769.565 & 968.236 & 5903.811 & 1142.798 \\
\hline AIC & -8971.460 & -1940.549 & -9199.762 & -1856.853 & -9523.13 & -1920.471 & -11791.620 & -2269.596 \\
\hline BIC & -8928.289 & -1911.135 & -9156.591 & -1827.439 & -9479.96 & -1891.057 & -11748.450 & -2240.282 \\
\hline
\end{tabular}

Table 4 - Asian markets. Correlation of MSCI index returns for India, China, Japan and The MSCI Emerging and Frontier Markets (EFM) Index with the MSCI Russia and the MSCI World, during the pre-crisis and the crisis periods. Dynamic conditional correlation $\mathrm{AR}(1)-\mathrm{MGARCH}(1,1)$ mean and variance model parameters and diagnostics are reported. Standard errors are given in brackets. The pre-crisis and the crisis periods are November 2007-February 2014 and March $2014-$ April 2015, respectively.

As can be seen in Table 4, the dynamic correlations between the MSCI Russia Index and the $\mathrm{MSCl}$ indices of India, China, and the $\mathrm{MSCl}$ Emerging and Frontier Markets (EFM) Index 
decreased considerably during the crisis period, with the decrease in correlation ranging from $47 \%$ to $71 \%$. The case of Japan, on the other hand, does not suggest a large change in correlation. ${ }^{14}$

The returns in all markets also exhibit decreased correlation with the MSCI World, though one of a smaller magnitude comparing to the decrease in correlation with the Russian market.

\begin{tabular}{|c|c|c|c|c|c|c|c|c|c|c|}
\hline \multirow{2}{*}{$\begin{array}{l}\text { Emerging } \\
\text { markets }\end{array}$} & \multicolumn{2}{|c|}{ HUN } & \multicolumn{2}{|c|}{ POL } & \multicolumn{2}{|c|}{ CZC } & \multicolumn{2}{|c|}{ BRA } & \multicolumn{2}{|c|}{ TUR } \\
\hline & Pre-crisis & Crisis & Pre-crisis & Crisis & Pre-crisis & Crisis & Pre-crisis & Crisis & Pre-crisis & Crisis \\
\hline \multicolumn{11}{|c|}{ Mean model } \\
\hline RUSSIA & $\begin{array}{c}0.323^{\star * *} \\
(0.032) \\
P<0.0001\end{array}$ & $\begin{array}{c}0.304^{* * *} \\
(0.115) \\
P=0.008\end{array}$ & $\begin{array}{c}0.345^{\star \star *} \\
(0.029) \\
P<0.0001\end{array}$ & $\begin{array}{c}0.061 \\
(0.057) \\
P=0.286\end{array}$ & $\begin{array}{l}0.284^{\star * *} \\
(0.024) \\
P<0.0001\end{array}$ & $\begin{array}{l}0.042 \\
(0.033) \\
P=0.201\end{array}$ & $\begin{array}{c}0.087^{* * *} \\
(0.019) \\
P<0.0001\end{array}$ & $\begin{array}{c}0.192^{* * *} \\
(0.021) \\
P<0.0001\end{array}$ & $\begin{array}{c}0.293^{* * *} \\
(0.028) \\
P<0.0001\end{array}$ & $\begin{array}{c}0.195^{\star * *} \\
(0.053) \\
P<0.0001\end{array}$ \\
\hline WORLD & $\begin{array}{c}1.137^{\star * *} \\
(0.069) \\
P<0.0001\end{array}$ & $\begin{array}{c}0.594^{\star * *} \\
(0.203) \\
P=0.004\end{array}$ & $\begin{array}{c}0.969^{\star * *} \\
(0.055) \\
P<0.0001\end{array}$ & $\begin{array}{c}0.807^{\star * *} \\
(0.133) \\
P<0.0001\end{array}$ & $\begin{array}{l}0.556^{\star \star \star} \\
(0.050) \\
\mathrm{P}<0.0001\end{array}$ & $\begin{array}{l}0.496^{\star * *} \\
(0.122) \\
P<0.0001\end{array}$ & $\begin{array}{c}1.332^{\star * *} \\
(0.0414) \\
P<0.0001\end{array}$ & $\begin{array}{c}1.336^{\star * *} \\
(0.044) \\
P<0.0001\end{array}$ & $\begin{array}{c}0.742^{* \star *} \\
(0.060) \\
P<0.0001\end{array}$ & $\begin{array}{c}0.732^{\star * *} \\
(0.220) \\
P=0.001\end{array}$ \\
\hline Constant & $\begin{array}{c}-0.00022 \\
(0.00038) \\
P=0.568\end{array}$ & $\begin{array}{l}0.00041 \\
(0.0077) \\
P=0.597\end{array}$ & $\begin{array}{c}0.000034 \\
(0.00030) \\
P=0.909\end{array}$ & $\begin{array}{c}-0.00073 \\
(0.00053) \\
P=0.172\end{array}$ & $\begin{array}{l}-0.00011 \\
(0.00030) \\
P=0.724\end{array}$ & $\begin{array}{l}0.00017 \\
(0.00058) \\
P=0.768\end{array}$ & $\begin{array}{c}-0.000245 \\
(0.00028) \\
P=0.386\end{array}$ & $\begin{array}{c}-0.00033 \\
(0.00096) \\
P=0.732\end{array}$ & $\begin{array}{c}0.00042 \\
(0.00037) \\
P=0.243\end{array}$ & $\begin{array}{c}0.000363 \\
(0.00093) \\
P=0.696\end{array}$ \\
\hline \multicolumn{11}{|c|}{ Multiplicative heteroskedasticity model } \\
\hline arch & $\begin{array}{c}0.064^{\star \star \star} \\
(0.019) \\
P=0.001\end{array}$ & $\begin{array}{l}0.091^{* *} \\
(0.038) \\
P=0.032\end{array}$ & $\begin{array}{c}0.058^{\star \star \star} \\
(0.018) \\
P=0.002\end{array}$ & $\begin{array}{c}0.027^{\star * *} \\
(0.009) \\
\mathrm{P}=0.001\end{array}$ & $\begin{array}{l}0.039^{* *} \\
(0.017) \\
P=0.022\end{array}$ & $\begin{array}{l}0.034^{* *} \\
(0.012) \\
P=0.020\end{array}$ & $\begin{array}{l}0.143^{\star \star \star} \\
(0.0515) \\
P=0.005\end{array}$ & $\begin{array}{l}0.043^{* *} \\
(0.017) \\
P=0.049\end{array}$ & $\begin{array}{c}0.060^{\star * *} \\
(0.016) \\
P<0.0001\end{array}$ & $\begin{array}{c}0.050^{* \star *} \\
(0.014) \\
P<0.0001\end{array}$ \\
\hline garch & $\begin{array}{c}0.871^{\star * *} \\
(0.033) \\
P<0.0001\end{array}$ & $\begin{array}{c}0.627^{\star \star *} \\
(0.041) \\
P<0.0001\end{array}$ & $\begin{array}{c}0.899^{\star * *} \\
(0.026) \\
P<0.0001\end{array}$ & $\begin{array}{c}0.896^{\star \star *} \\
(0.190) \\
P<0.0001\end{array}$ & $\begin{array}{l}0.910^{\star \star \star} \\
(0.029) \\
\mathrm{P}<0.0001\end{array}$ & $\begin{array}{l}0.799^{\star \star \star} \\
(0.128) \\
P<0.0001\end{array}$ & $\begin{array}{c}0.548^{\star \star *} \\
(0.115) \\
P<0.0001\end{array}$ & $\begin{array}{c}0.892^{\star \star *} \\
(0.0459) \\
P<0.0001\end{array}$ & $\begin{array}{c}0.910^{\star \star *} \\
(0.024) \\
P<0.0001\end{array}$ & $\begin{array}{c}0.714^{\star * \star} \\
(0.159) \\
P<0.0001\end{array}$ \\
\hline RUSSIA & $\begin{array}{c}14.011^{\star *} \\
(5.697) \\
P=0.014\end{array}$ & $\begin{array}{c}29.413^{\star \star \star} \\
(7.028) \\
P<0.0001\end{array}$ & $\begin{array}{c}-9.011 \\
(10.329) \\
P=0.383 \\
\end{array}$ & & 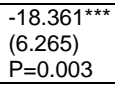 & $\begin{array}{l}30.356^{\star \star \star} \\
(5.778) \\
P<0.0001\end{array}$ & $\begin{array}{l}-11.825 \\
(12.474) \\
P=0.343 \\
\end{array}$ & $\begin{array}{c}-4.965 \\
(7.615) \\
P=0.514\end{array}$ & $\begin{array}{c}12.382 \\
(8.462) \\
P=0.143\end{array}$ & $\begin{array}{c}8.897 \\
(7.394) \\
P=0.229 \\
\end{array}$ \\
\hline WORLD & $\begin{array}{c}-90.600^{\star \star \star} \\
(7.675) \\
P<0.0001\end{array}$ & $\begin{array}{c}-69.610^{* * *} \\
(49.988) \\
P<0.0001\end{array}$ & $\begin{array}{c}-59.458^{\star \star \star} \\
(22.562) \\
P=0.008\end{array}$ & & $\begin{array}{l}-35.826^{\star \star \star} \\
(15.534) \\
P=0.003\end{array}$ & $\begin{array}{l}-138.75^{\star \star \star} \\
(42.094) \\
P=0.001\end{array}$ & $\begin{array}{l}-52.463^{*} \\
(27.102) \\
P=0.053\end{array}$ & $\begin{array}{c}-178.298^{* * *} \\
(40.934) \\
P<0.0001\end{array}$ & $\begin{array}{c}-73.743^{\star * *} \\
(10.078) \\
P<0.0001\end{array}$ & $\begin{array}{l}-48.349 \\
(42.883) \\
P=0.260\end{array}$ \\
\hline Constant & $\begin{array}{c}-11.210^{\star \star \star} \\
(0.339) \\
P<0.0001\end{array}$ & $\begin{array}{c}-9.966^{\star \star \star} \\
(0.694) \\
P<0.0001\end{array}$ & $\begin{array}{c}-12.091^{\star \star *} \\
(0.336) \\
P<0.0001\end{array}$ & $\begin{array}{c}6.43 \mathrm{e}-06 \\
(0.000015) \\
P=0.662\end{array}$ & $\begin{array}{l}-11.999^{\star \star \star} \\
(0.381) \\
\mathrm{P}<0.0001\end{array}$ & $\begin{array}{l}-11.265^{\star \star \star} \\
(0.743) \\
\mathrm{P}<0.0001\end{array}$ & $\begin{array}{c}-10.340^{\star \star *} \\
(0.229) \\
P<0.0001\end{array}$ & $\begin{array}{c}-11.399^{\star \star \star} \\
(0.656) \\
P<0.0001\end{array}$ & $\begin{array}{c}-11.883^{\star \star \star} \\
(0.467) \\
P<0.0001\end{array}$ & $\begin{array}{c}-9.783^{\star \star *} \\
(0.649) \\
P<0.0001\end{array}$ \\
\hline \multicolumn{11}{|c|}{ Model diagnostics } \\
\hline arch+garch & 0.935 & 0.718 & 0.957 & 0.923 & 0.949 & 0.833 & 0.691 & 0.935 & 0.970 & 0.764 \\
\hline Wald $\chi^{2}$ & $\begin{array}{c}1041.30^{* * *} \\
\mathrm{P}<0.0001\end{array}$ & $\begin{array}{c}47.06^{\star \star *} \\
\mathrm{P}<0.0001\end{array}$ & $\begin{array}{c}1382.80^{* * *} \\
\mathrm{P}<0.0001\end{array}$ & $\begin{array}{c}74.01^{* * *} \\
P<0.0001\end{array}$ & $\begin{array}{l}852.57^{* * *} \\
P<0.0001\end{array}$ & $\begin{array}{l}25.85^{\star \star \star} \\
P<0.0001\end{array}$ & $\begin{array}{c}2505.57^{\star \star \star} \\
P<0.0001\end{array}$ & $\begin{array}{c}85.56^{\star \star \star} \\
\mathrm{P}<0.0001\end{array}$ & $\begin{array}{l}946.52^{\star \star \star} \\
P<0.0001\end{array}$ & $\begin{array}{c}60.81^{* * *} \\
P<0.0001\end{array}$ \\
\hline $\mathbf{L L}$ & 4295.548 & 839.889 & 4664.697 & 956.928 & 4746.603 & 934.433 & 4810.817 & 777.188 & 4362.882 & 803.109 \\
\hline AIC & -8575.095 & -1663.777 & -9313.394 & -1901.856 & -9477.207 & -1852.867 & -9745.830 & -1538.376 & -8709.764 & -1590.218 \\
\hline BIC & -8531.924 & -1634.363 & -9270.223 & -1879.795 & -9434.036 & -1832.453 & -9702.659 & -1508.962 & -8666.593 & -1560.804 \\
\hline
\end{tabular}

Table 5 - Emerging markets. Correlation of MSCI index returns for Hungary, Poland, Czech Republic, Brazil and Turkey with the MSCI Russia and the MSCI World, during the pre-crisis and the crisis periods. Dynamic conditional correlation $\mathrm{AR}(1)-\mathrm{MGARCH}(1,1)$ mean and variance model parameters and diagnostics are reported. Standard errors are given in brackets. The pre-crisis and the crisis periods are November 2007-February 2014 and March 2014-April 2015, respectively.

As shown in Table 5, Brazil is the only country to show evidence of contagious effects from Russia. In fact, prior to the Ukrainian crisis, a $1 \%$ increase in the Russian equity return was associated with a $8.7 \%$ increase in the Brazilian stock return, whereas after the crisis this association

\footnotetext{
${ }^{14}$ Note that the formal tests to detect correlation changes are reported in the next section. Appendix Tables A9 and A10 show the values of the information criteria for each model type in relation to both time periods.
} 
increased to $19.2 \%$. Brazil and Russia were among the ten worst performing markets in 2014 so the increase in correlation between these markets' returns in the crisis period could be explained by idiosyncratic downside risk factors occurring simultaneously, as well as by a similar exposure of both countries to decline in oil prices. As for other emerging markets, Hungary and Turkey did not exhibit any change in their relationship with the Russian market. In Czech Republic and Poland, correlations have dropped considerably although their coefficients do not imply reliability due to their large standard errors and thus inconclusive test statistics. With regards to the world return, correlations decreased in all markets except Brazil, where we were only able to observe a small decrease ($0.3 \%$ ). Correlations have notably decreased for: Hungary (ca. 47.8\%), Poland (16.7\%), Czech Republic (10.8\%) and Turkey (1.3\%).

\begin{tabular}{|c|c|c|c|c|c|c|c|c|c|c|}
\hline \multirow{2}{*}{$\begin{array}{l}\text { Frontier } \\
\text { markets }\end{array}$} & \multicolumn{2}{|c|}{ ROM } & \multicolumn{2}{|c|}{ BUL } & \multicolumn{2}{|c|}{ KZK } & \multicolumn{2}{|c|}{ UKR } & \multicolumn{2}{|c|}{ EST } \\
\hline & Pre-crisis & Crisis & Pre-crisis & Crisis & Pre-crisis & Crisis & Pre-crisis & Crisis & Pre-crisis & Crisis \\
\hline \multicolumn{11}{|c|}{ Mean model } \\
\hline RUSSIA & $\begin{array}{c}0.306^{* * *} \\
(0.033) \\
P<0.0001\end{array}$ & $\begin{array}{c}0.004 \\
(0.026) \\
P=0.882\end{array}$ & $\begin{array}{c}0.140^{* * *} \\
(0.026) \\
P<0.0001\end{array}$ & $\begin{array}{c}-0.038 \\
(0.041) \\
P=0.356\end{array}$ & $\begin{array}{c}0.321^{* * *} \\
(0.030) \\
P<0.0001\end{array}$ & $\begin{array}{c}0.037 \\
(0.064) \\
P=0.563\end{array}$ & $\begin{array}{c}0.232^{* * *} \\
(0.034) \\
P<0.0001\end{array}$ & $\begin{array}{c}-0.102 \\
(0.300) \\
P=0.733\end{array}$ & $\begin{array}{c}0.129^{\star * *} \\
(0.030) \\
P<0.0001\end{array}$ & $\begin{array}{l}-0.0156 \\
(0.0292) \\
P=0.591\end{array}$ \\
\hline WORLD & $\begin{array}{c}0.622^{* \star *} \\
(0.070) \\
P<0.0001\end{array}$ & $\begin{array}{c}0.581^{* * *} \\
(0.109) \\
\mathrm{P}<0.0001\end{array}$ & $\begin{array}{c}0.366^{\star \star *} \\
(0.054) \\
P<0.0001\end{array}$ & $\begin{array}{c}0.154 \\
(0.155) \\
P=0.318\end{array}$ & $\begin{array}{c}0.157^{\star \star} \\
(0.062) \\
P=0.012\end{array}$ & $\begin{array}{c}0.629^{\star * *} \\
(0.177) \\
P<0.0001\end{array}$ & $\begin{array}{c}0.292^{\star \star *} \\
(0.067) \\
P<0.0001\end{array}$ & $\begin{array}{c}0.641 \\
(0.646) \\
P=0.321\end{array}$ & $\begin{array}{l}0.470^{* \star *} \\
(0.0558) \\
P<0.0001\end{array}$ & $\begin{array}{c}0.505^{\star \star \star} \\
(0.116) \\
\mathrm{P}<0.0001\end{array}$ \\
\hline Constant & $\begin{array}{l}0.00011 \\
(0.0004) \\
P=0.786\end{array}$ & $\begin{array}{c}-0.00029 \\
(0.00054) \\
P=0.587\end{array}$ & $\begin{array}{c}-0.00068^{*} \\
(0.00037) \\
P=0.069\end{array}$ & $\begin{array}{c}-0.0016^{* *} \\
(0.0007) \\
P=0.033\end{array}$ & $\begin{array}{c}0.00018 \\
(0.00038) \\
P=0.622\end{array}$ & $\begin{array}{c}0.00048 \\
(0.00077) \\
P=0.536\end{array}$ & $\begin{array}{c}-0.00148^{\star * *} \\
(0.00042) \\
P<0.0001\end{array}$ & $\begin{array}{c}0.00466 \\
(0.00606) \\
P=0.442\end{array}$ & $\begin{array}{c}-0.00003 \\
(0.00035) \\
P=0.929\end{array}$ & $\begin{array}{l}-0.0012^{\star *} \\
(0.0006) \\
P=0.047\end{array}$ \\
\hline \multicolumn{11}{|c|}{ Multiplicative heteroskedasticity model } \\
\hline arch & $\begin{array}{c}0.026^{\star *} \\
(0.0126) \\
P=0.040\end{array}$ & $\begin{array}{c}0.023^{\star * *} \\
(0.0038) \\
P<0.0001\end{array}$ & $\begin{array}{c}0.068^{\star \star \star} \\
(0.0169) \\
P<0.0001\end{array}$ & $\begin{array}{c}0.095^{\star *} \\
(0.045) \\
P=0.049\end{array}$ & $\begin{array}{c}0.079^{\star *} \\
(0.028) \\
\mathrm{P}=0.005\end{array}$ & $\begin{array}{c}0.092^{\star *} \\
(0.040) \\
P=0.049\end{array}$ & $\begin{array}{c}0.176^{\star \star *} \\
(0.0390) \\
P<0.0001\end{array}$ & $\begin{array}{c}1.212 \\
(2.071) \\
P=0.558\end{array}$ & $\begin{array}{c}0.0995^{\star *} \\
(0.023) \\
P=0.035\end{array}$ & $\begin{array}{c}0.0921^{\star *} \\
(0.025) \\
P=0.037\end{array}$ \\
\hline garch & $\begin{array}{c}0.956^{* \star \star} \\
(0.015) \\
P<0.0001\end{array}$ & $\begin{array}{c}0.885^{\star \star *} \\
(0.091) \\
P<0.0001\end{array}$ & $\begin{array}{c}0.866^{\star \star *} \\
(0.040) \\
P<0.0001\end{array}$ & $\begin{array}{c}0.811^{\star * *} \\
(0.053) \\
P<0.0001\end{array}$ & $\begin{array}{c}0.859^{* \star *} \\
(0.042) \\
P<0.0001\end{array}$ & $\begin{array}{c}0.843^{\star * *} \\
(0.066) \\
P<0.0001\end{array}$ & $\begin{array}{c}0.807^{\star * *} \\
(0.041) \\
P<0.0001\end{array}$ & $\begin{array}{c}-0.020^{* *} \\
(0.009) \\
P=0.038\end{array}$ & $\begin{array}{c}0.868^{* * *} \\
(0.072) \\
P<0.0001\end{array}$ & $\begin{array}{c}0.732^{* * *} \\
(0.041) \\
P<0.0001\end{array}$ \\
\hline RUSSIA & $\begin{array}{c}4.873 \\
(3.371) \\
P=0.148\end{array}$ & $\begin{array}{c}26.75^{\star *} \\
(9.073) \\
P=0.003\end{array}$ & $\begin{array}{c}-22.269^{\star * *} \\
(4.537) \\
P<0.0001\end{array}$ & $\begin{array}{c}28.321^{* \star *} \\
(7.929) \\
P<0.0001\end{array}$ & $\begin{array}{c}15.783^{\star *} \\
(6.713) \\
P=0.019\end{array}$ & $\begin{array}{c}-44.28^{\star * *} \\
(6.802) \\
P<0.0001\end{array}$ & $\begin{array}{c}7.744^{*} \\
(4.093) \\
P=0.059\end{array}$ & - & $\begin{array}{c}25.342^{* \star *} \\
(5.524) \\
P<0.0001\end{array}$ & $\begin{array}{c}3.937 \\
(10.586) \\
P=0.710\end{array}$ \\
\hline WORLD & $\begin{array}{c}77.386^{* * *} \\
(15.221) \\
P<0.0001\end{array}$ & $\begin{array}{c}-57.39 \\
(48.99) \\
P=0.241\end{array}$ & $\begin{array}{c}-25.01 \\
(16.248) \\
P=0.124\end{array}$ & $\begin{array}{c}-70.44 \\
(45.90) \\
P=0.125\end{array}$ & $\begin{array}{c}-94.719^{\star * *} \\
(8.845) \\
P<0.0001\end{array}$ & $\begin{array}{c}-112.059 \\
(98.179) \\
P=0.254\end{array}$ & $\begin{array}{c}55.820^{\star * *} \\
(17.005) \\
P=0.001\end{array}$ & - & $\begin{array}{l}-55.626 \\
(37.776) \\
P=0.141\end{array}$ & $\begin{array}{c}-45.040^{\star *} \\
(11.587) \\
P=0.041\end{array}$ \\
\hline Constant & $\begin{array}{c}-12.791^{* * *} \\
(0.468) \\
P<0.0001\end{array}$ & $\begin{array}{c}-11.85^{* * *} \\
(1.18) \\
P<0.0001\end{array}$ & $\begin{array}{c}11.287^{* * *} \\
(0.469) \\
P<0.0001\end{array}$ & $\begin{array}{c}-11.08^{* * *} \\
(0.430) \\
P<0.0001\end{array}$ & $\begin{array}{c}-11.347^{* * *} \\
(0.396) \\
P<0.0001\end{array}$ & $\begin{array}{c}-11.689^{* * *} \\
(0.823) \\
P<0.0001\end{array}$ & $\begin{array}{c}-11.359^{\star \star *} \\
(0.518) \\
P<0.0001\end{array}$ & - & $\begin{array}{c}-11.580^{* \star *} \\
(0.811) \\
P<0.0001\end{array}$ & $\begin{array}{c}-9.681^{* * *} \\
(0.736) \\
P<0.0001\end{array}$ \\
\hline \multicolumn{11}{|c|}{ Model diagnostics } \\
\hline arch+garch & 0.982 & 0.908 & 0.934 & 0.906 & 0.938 & 0.935 & 0.983 & 1.192 & 0.9675 & 0.8241 \\
\hline Wald $\chi^{2}$ & $\begin{array}{l}476.31^{* * *} \\
P<0.0001\end{array}$ & $\begin{array}{c}40.08^{\star * *} \\
P<0.0001\end{array}$ & $\begin{array}{c}24.44^{\star * *} \\
P<0.0001\end{array}$ & $\begin{array}{c}25.25^{\star * *} \\
P<0.0001\end{array}$ & $\begin{array}{l}303.63^{* * *} \\
P<0.0001\end{array}$ & $\begin{array}{c}15.32^{* * *} \\
P=0.0005\end{array}$ & $\begin{array}{l}146.77^{\star * *} \\
P<0.0001\end{array}$ & $\begin{array}{c}1.68^{* * *} \\
P=0.4324\end{array}$ & $\begin{array}{l}223.81^{\star * \star} \\
P<0.0001\end{array}$ & $\begin{array}{c}21.82^{\star * *} \\
\mathrm{P}<0.0001\end{array}$ \\
\hline LL & 4328.399 & 947.164 & 4431.028 & 843.87 & 4397.688 & 770.573 & 4170.701 & 564.1303 & 4414.584 & 928.133 \\
\hline AIC & -8640.797 & -1878.329 & -8846.056 & -1671.743 & -8779.376 & -1525.146 & -8325.402 & -1116.261 & -8813.168 & -1840.266 \\
\hline BIC & -8597.626 & -1848.915 & -8802.886 & -1642.329 & -8736.206 & -1495.732 & -8282.231 & -1094.200 & -8769.997 & -1810.852 \\
\hline
\end{tabular}

Table 6 - Frontier markets. Correlation of MSCI index returns for Romania, Bulgaria, Kazakhstan, Ukraine and Estonia with the MSCI Russia and the MSCI World, during the pre-crisis and the crisis periods. Dynamic conditional correlation $\mathrm{AR}(1)-\mathrm{MGARCH}(1,1)$ mean and variance model parameters and diagnostics are reported. Standard errors are given in brackets. The pre-crisis and the crisis periods are November 2007-February 2014 and March 2014-April 2015, respectively.

Table 6 shows the unconditional correlations of five frontier markets and the Russian equity market before and during the crisis. It is remarkable how correlations have dropped in all cases; most of the correlations even become negative and insignificant during the crisis. Moreover, correlations with the world return decreased by ca. $7 \%$ in Romania and increased by a similar extent in Estonia. Estonia became substantially more associated with the world during the crisis. This is 
even more the case in Kazakhstan, which was expected to show even tighter links to the Russian market.

Having used a DCC MGARCH model to derive the correlations between Russian stock returns and the returns observed in our sample of international markets, we now turn to testing for the presence of significant changes in correlation using Fisher's z-transformation.

\begin{tabular}{|c|c|c|c|c|c|c|}
\hline \multirow{2}{*}{ Index } & \multicolumn{2}{|c|}{ Pre-crisis } & \multicolumn{2}{|c|}{ Crisis } & \multirow{2}{*}{$\mathbf{z}$} & \multirow{2}{*}{$\begin{array}{c}\text { Decoupling (D), } \\
\text { Contagion (C) }\end{array}$} \\
\hline & $\rho$ & $\boldsymbol{\sigma}$ & $\rho$ & $\sigma$ & & \\
\hline JAP & -0.028 & 0.023 & 0.092 & 0.023 & -1.88 & C \\
\hline BRA & 0.087 & 0.019 & 0.192 & 0.021 & -1.68 & $\mathbf{C}^{\star}$ \\
\hline ROM & 0.306 & 0.033 & 0.004 & 0.026 & 4.89 & $\mathrm{D}$ \\
\hline BUL & 0.140 & 0.026 & -0.038 & 0.041 & 2.80 & $\mathrm{D}$ \\
\hline KZK & 0.321 & 0.030 & 0.037 & 0.064 & 4.63 & $\mathrm{D}$ \\
\hline UKR & 0.232 & 0.034 & -0.102 & 0.300 & 5.31 & $\mathrm{D}$ \\
\hline CZC & 0.284 & 0.024 & 0.042 & 0.033 & 3.92 & D \\
\hline EST & 0.129 & 0.030 & -0.016 & 0.0292 & 2.28 & $\mathrm{D}$ \\
\hline POL & 0.345 & 0.029 & 0.061 & 0.057 & 4.68 & $\mathrm{D}$ \\
\hline UK & 0.118 & 0.011 & 0.005 & 0.014 & 1.78 & $\mathrm{D}$ \\
\hline $\mathrm{CHN}$ & 0.167 & 0.031 & 0.049 & 0.028 & 1.87 & $\mathrm{D}^{*}$ \\
\hline FRA & 0.124 & 0.013 & -0.030 & 0.015 & 2.42 & $\mathrm{D}^{*}$ \\
\hline GER & 0.146 & 0.013 & -0.030 & 0.015 & 2.77 & $\mathbf{D}^{\star}$ \\
\hline USA & 0.133 & 0.009 & -0.022 & 0.084 & 2.44 & $\mathbf{D}^{*}$ \\
\hline EM/FM & 0.195 & 0.012 & 0.106 & 0.020 & 3.82 & $\mathbf{D}^{\star}$ \\
\hline NED & 0.110 & 0.014 & 0.009 & 0.019 & 1.59 & $\mathrm{~N}$ \\
\hline HUN & 0.323 & 0.032 & 0.304 & 0.115 & 0.16 & $\mathrm{~N}$ \\
\hline IND & 0.164 & 0.032 & 0.066 & 0.029 & 0.12 & $\mathrm{~N}$ \\
\hline TUR & 0.293 & 0.028 & 0.195 & 0.053 & 1.63 & $\mathrm{~N}$ \\
\hline
\end{tabular}

Table 7 Tests of contagion. Fisher's transformation is applied to test for a change in the dynamic correlation between the crisis country (Russia) and the 18 international markets. $\mathrm{N}$ indicates that no contagion was detected. Asterisks indicate that the change in correlation over the two periods is statistically significant $(z>1.65$ and $t>1.65$ for MGARCH coefficients in both periods) at the $5 \%$ level.

The relationships characterized by significant changes in correlation with the Russian market are denoted with asterisks in Table 7 . According to our results, the most pronounced international trend seems to be that of the Russian market decoupling from other countries ${ }^{15}$. This is true in $83 \%$ of all significant instances of the recorded changes in correlation. In most cases, decoupling seems to have occurred but cannot be directly confirmed due to the MGARCH coefficient on the Russian return becoming insignificant in the crisis period. Given that, in many cases, correlation coefficients are still positive after the crisis, this result possibly implying that the $\mathrm{MSCl}$ Russia returns lost any explanatory power in the crisis period. To this extent, the Russian market showed signs of decoupling

15 This result is also confirmed by the rolling six-monthly correlations, shown in Figs. A5-A8, which suggest a falling correlation between the Russian market and the majority of other markets. 
from other markets in $86 \%$ of such cases. Moreover, no change in correlation occurred for Hungary, India and Turkey. We were only able to observe one instance of contagious effects associated with Russia. This was the case for Brazil, where correlations with Russian market returns increased by ca. 55\%. As previously mentioned, Brazil and Russia were among the ten worst performing markets in 2014 , thus the increase in correlation between returns in these two markets during the crisis period could be explained by the idiosyncratic downside risk factors occurring simultaneously, as well as by similar exposure of both countries to decline in oil prices. On the other hand, we were able to find evidence of decoupling of the Russian market in a series of major markets, such as China, France, the U.S. and Germany. Returns in these markets experienced falls in correlation with the Russian market of magnitudes between $71-84 \%$ (see Table 8). Similarly, emerging and frontier markets as a whole, represented by The MSCI Emerging and Frontier Markets (EFM) Index, experienced a fall in correlation by ca. $46 \%$.

\begin{tabular}{cccccc}
\hline & CHN & EM/FM & FRA & GER & USA \\
\hline RUS & $-70.66 \%$ & $-45.64 \%$ & $-75.48 \%$ & $-79.18 \%$ & $-83.53 \%$ \\
& & & & & \\
WLD & $-2.55 \%$ & $+14.98 \%$ & $+5.69 \%$ & $+15.07 \%$ & $+0.09 \%$ \\
\hline
\end{tabular}

Table 8 Significant decrease in correlation between the MSCI Russia the MSCI indices for China, France, Germany, the US, and The MSCI Emerging and Frontier Markets (EFM) Index.

These findings strongly support the hypothesis of major decoupling of the Russian equity market from the markets of China, France, Germany, the U.S., as well as emerging and frontier markets as a whole (see Table 8).

In our study, $90 \%$ of cases satisfy the conditions for contagion (an increase in correlation with the Russian market) if we do not correct for the dynamic volatility bias. On the other hand, a decrease in correlations occurred in ca. $85 \%$ of cases when accounting for the bias. This result emphasizes that results can be very misleading if the methodological issues originally raised by Forbes and Rigobon (2002) are not taken into account.

We now turn our attention to deciphering the impact of the Russian equity return volatility on the volatility of other stock markets in our sample. In consideration of the multiplicative heteroskedasticity models successfully estimated in both periods, Russian equity market volatility is positively related to the volatility in the majority of considered markets. We find evidence that an important transmission of volatility associated with the Russian equity market occurred in the markets of Japan, Hungary, Czech Republic and Bulgaria. On the other hand, the volatility related to the Russian market significantly decreased in Kazakhstan. In fact, we record a large negative volatility co-movement between the Russian and Kazakhstani equity markets. Moreover, markets for which higher periods of volatility in the crisis period are associated with higher periods of volatility in the 
Russian market during the same period are Japan, India, Hungary, China, Czech Republic, Romania and Bulgaria. ${ }^{16}$

We additionally investigate whether international market returns have been subject to asymmetric shocks, meaning that positive and negative innovations had different magnitudes of effect on the mean return.

\begin{tabular}{|c|c|c|c|c|}
\hline Index & \multicolumn{2}{|c|}{$\begin{array}{c}\text { Stable period } \\
(\mathbf{2 0 0 7 - 2 0 1 4 )}\end{array}$} & \multicolumn{2}{|c|}{$\begin{array}{c}\text { Turmoil period } \\
(\mathbf{2 0 1 4 - 2 0 1 5 )}\end{array}$} \\
\hline ROM & $\mathrm{P}<0.0001$ & & $\mathrm{P}<0.0001$ & ${ }^{*}$ \\
\hline BUL & $\mathrm{P}<0.0001$ & ${ }^{*}$ & $\mathrm{P}<0.0001$ & ${ }^{*}$ \\
\hline KZK & $\mathrm{P}<0.0001$ & ${ }^{*}$ & $\mathrm{P}<0.0001$ & ${ }^{*}$ \\
\hline UKR & $\mathrm{P}<0.0001$ & & $\mathrm{P}<0.0001$ & \\
\hline CZC & $\mathrm{P}<0.0001$ & & $\mathrm{P}<0.0001$ & ${ }^{*}$ \\
\hline EST & $\mathrm{P}<0.0001$ & & $\mathrm{P}<0.0001$ & \\
\hline HUN & $\mathrm{P}<0.0001$ & ${ }^{*}$ & $\mathrm{P}<0.0001$ & ${ }^{*}$ \\
\hline POL & $\mathrm{P}<0.0001$ & ${ }^{*}$ & $\mathrm{P}<0.0001$ & ${ }^{*}$ \\
\hline EM/FM & $\mathrm{P}<0.0001$ & & $\mathrm{P}<0.0001$ & ${ }^{*}$ \\
\hline BRA & $\mathrm{P}<0.0001$ & ${ }^{*}$ & $\mathrm{P}<0.0001$ & ${ }^{*}$ \\
\hline IND & $\mathrm{P}<0.0001$ & ${ }^{*}$ & $\mathrm{P}<0.0001$ & ${ }^{*}$ \\
\hline CHN & $\mathrm{P}<0.0001$ & ${ }^{*}$ & $\mathrm{P}<0.0001$ & \\
\hline TUR & $\mathrm{P}<0.0001$ & ${ }^{*}$ & $\mathrm{P}<0.0001$ & ${ }^{*}$ \\
\hline JAP & $\mathrm{P}<0.0001$ & ${ }^{*}$ & $\mathrm{P}<0.0001$ & \\
\hline RUS & $\mathrm{P}<0.0001$ & & $\mathrm{P}<0.0001$ & ${ }^{*}$ \\
\hline FRA & $\mathrm{P}<0.0001$ & ${ }^{*}$ & $\mathrm{P}<0.0001$ & ${ }^{*}$ \\
\hline GER & $\mathrm{P}<0.0001$ & ${ }^{*}$ & $\mathrm{P}<0.0001$ & ${ }^{*}$ \\
\hline NED & $\mathrm{P}<0.0001$ & & $\mathrm{P}<0.0001$ & ${ }^{*}$ \\
\hline UK & $\mathrm{P}<0.0001$ & & $\mathrm{P}<0.0001$ & ${ }^{*}$ \\
\hline US & $\mathrm{P}<0.0001$ & & $\mathrm{P}<0.0001$ & ${ }^{*}$ \\
\hline
\end{tabular}

Table 9 Asymmetric AR-GARCH joint significance of coefficients, where $\mathrm{P}<0.0001$ indicates significance at all levels. The explanatory variables are world index return and Russian return; the dependent variable is the return from the markets in the first column. Asterisks indicate significance of the asymmetric volatility term.

The asterisks in Table 9 indicate those countries displaying asymmetric volatility spillover effects. Notably, the 2014 crisis period coincided with the appearance of asymmetric effects in Romania, Czech Republic, Netherlands, UK, U.S. and in emerging and frontier markets as a whole. Overall, $55 \%$ of equity returns showed evidence of asymmetric effects. In ca. $37 \%$ of cases, asymmetric effects appeared after the crisis. On the other hand, the volatility of the world index return is shown to have a profound effect on most markets. The transmission of systematic risk from world markets decreased substantially in some countries (India, Japan and Czech Republic), whereas it noticeably increased only in Hungary.

Finally, we briefly review the factors affecting the Russian stock market both in terms of returns and volatility. Appendix Figure A1 shows the six-monthly rolling daily correlations between the Russian market returns and returns from investing in the oil market (Brent crude) and world markets (MSCI World Index). It is possible to notice the stability of the correlations between the

\footnotetext{
${ }^{16}$ It was not possible to specify conditional risk factors in the multiplicative heteroskedasticity equations for France, Germany, Netherlands, UK, US, Poland and Ukraine due to the encounter of discontinuous estimation regions.
} 
Russian equity market return and returns observed in both world equity markets and oil markets. A falling trend towards 2012 between Russian and world equity markets, as well as a simultaneous protracted increase in the correlation with oil returns are particularly notable. The figure suggests that world markets are becoming less associable to the Russian stock market, whereas Russian stocks returns and oil returns are becoming more associated.

\section{Discussion}

Our analysis shows that the 2014 Ukrainian crisis is associated with a fall in the interdependence between the Russian stock market and the majority of international markets in our sample. Even though this crisis represents a political and economic turmoil period that did not originate from financial markets, the affluence of sanctions, embargos and negative sentiment from world markets implies the possibility of profound repercussions on international financial markets. We therefore tested for the presence of contagious effects and analyzed the presence and nature of volatility spillovers from the Russian stock market onto other markets.

Among the main results, we find evidence of: (i) A profoundly decreased interdependence between the Russian equity market and 83 percent of developed, frontier and emerging markets, providing evidence that the Russian equity market has decoupled from global equity markets in the aftermath of the Ukrainian crisis; (ii) Contagious effects from Russia were found exclusively for the Brazilian market. The inferior performance of Brazilian and Russian markets in 2014 suggests that the increase in correlation between returns in these markets in the crisis period could be associated with the simultaneous effect of idiosyncratic downside risk factors as well as by a similar exposure of both countries to a declining oil price. No change in cross-market co-movements was found in the emerging markets of Hungary, India and Turkey; (iii) we show that Russian equity market volatility is positively related to equity volatility in the majority of international markets. Moreover, our results indicate that the Ukrainian crisis was characterized by large transmissions of volatility from Russia towards the markets of Japan, Hungary, Czech Republic and Bulgaria. On the other hand, volatility in Kazakhstan associated with the Russian market, where the co-movement with Russian equity returns was found to be negative, fell considerably. We find evidence of volatility interdependence between Russia and Japan, India, Hungary, China, Czech Republic, Romania and Bulgaria. Finally, we show that (iv) the Ukrainian crisis period coincided with the appearance of asymmetric effects in Romania, Czech Republic, Netherlands, the UK, the US and emerging and frontier markets as a whole. 
The main contributions of this paper are twofold. On one hand, we show that the Russian market became increasingly isolated from the majority of other stock markets. Such markets were not subject to contagious effects, rather showing signs of lower associations with the Russian market. This also applies to emerging and frontier markets and is in line with Serwa and Bohl (2005), who find that the Central and Eastern European stock markets do not appear to be more vulnerable to contagion than Western European markets. In addition, European markets, as well as emerging and frontier markets, did not appear to be affected by abnormal volatility during the Ukrainian crisis. However, we report large transmissions of volatility associated with the Russian market in the majority of global financial markets, especially emerging and frontier markets. Aside from such volatility interdependence, in terms of financial contagion, the results of this paper offer support to international investors including ex-Soviet, emerging and frontier market stocks in their portfolios, showing that, at least after one year, the Ukrainian crisis has not induced particular costs on these markets. Moreover, we show that the crisis concurred with the presence of asymmetric spillover effects as positive returns had a smaller impact on future volatility than negative returns of the same absolute magnitude, in the majority of world equity markets considered. This may be associated to the leverage effect (Andersen et al., 2001), whereby large negative returns increase financial and operating leverage in turn contributing towards the increase in equity return volatility (e.g. Christie, 1982; Black, 1976), This may raise liquidity concerns or may alternatively be the result of a volatility feedback effect (e.g. Campbell and Hentschel, 1992), which may have positive implications for equity options investors in emerging and frontier markets.

Most of the empirical evidence present in the literature on financial contagion either confirms the hypothesis of contagion (e.g. Chiang et al., 2007; Kenourgios, 2011; Dungey and Gajurel, 2014) or dismisses it (e.g. Forbes and Rigobon, 2002; Collins and Biekpe, 2002). Only in a few cases (e.g. Dooley and Hutchison, 2009; Dimitriou et al., 2013) did research studies find signs of decoupling during major crises, as in this study.

The main drawback of our analysis is the use of a single year of daily data (March 2014-April 2015) to represent the crisis period. However, our investigation is consistent and robust to a wide variety of model and data specifications, as discussed earlier. In addition, the possibility of selection bias was circumvented with the use of a comprehensive set of world markets and the dynamic volatility bias was avoided by using a heteroskedastic approach. 


\section{Conclusions}

The Russian economy was severely hurt by the impact of international sanctions and the decrease in oil prices. In this environment, the outlook for Russian equities remained at best unpredictable and at worst dire.

According to our results, the Russian market significantly decoupled from the majority of stock markets and should arguably become a special case in the minds of most investors. As far as the developments in capital markets are concerned, it appears that, as intended, the political and economic sanctions imposed on Russia were successful in generating idiosyncratic shock for the country with limited repercussions for the rest of the world.

Our results provide evidence that a decrease of international markets' returns correlation with Russian stock returns occurred rather uniformly across developed, emerging, and frontier markets, regardless of the strength of economic ties with Russia. Russian markets have not been so weakly correlated with global markets since the early 2000s, when Russia was barely part of international equity portfolios. With Russian financial markets increasingly driven by domestic news rather than global sentiment, the links of the Russian stock market with the rest of the world, and its immediate neighbors in particular, are likely to depend on the dynamics of the ruble, oil prices, capital outflows, indicators of the level of stress in the financial system and political news.

In view of the dramatic decline in market capitalization, its uncertain outlook, and the verified decoupling from world markets, Russia may now be on the path toward being downgraded from its emerging market status and its role in the BRICS is likely to gradually reduce. 


\section{Acknowledgments}

We wish to acknowledge financial support from the EU Commission for Horizon 2020 grant OJC361 (COSC) which enabled the creation of the UCL Centre for Comparative Studies of Emerging Economies. This study was partly funded by the British Economic and Social Research Council. We would also like to thank Marcus Miller (Warwick University) and Richard Green (Imperial College London) for useful suggestions. Finally, we wish to thank participants at University College London's 2015 SSEES Centennial Conference, where this paper was presented, for helpful discussions which improved the quality of the paper. 


\section{References}

1. Andersen, T. G., Bollerslev, T., Diebold, F. X., \& Ebens, H. (2001). The distribution of realized stock return volatility. Journal of financial economics, 61(1), 43-76.

2. Bae, K. H., Karolyi, G. A., \& Stulz, R. M. (2003). A new approach to measuring financial contagion. Review of Financial studies, 16(3), 717-763.

3. Bekaert, G., \& Hodrick, R. J. (1992). Characterizing predictable components in excess returns on equity and foreign exchange markets. The Journal of Finance, 47(2), 467-509.

4. Bekaert, G., Hodrick, R. J., \& Zhang, X. (2009). International stock return comovements. The Journal of Finance 64(6), 2591-2626.

5. Bekaert, G., Ehrmann, M., Fratzscher, M., \& Mehl, A. (2014). The global crisis and equity market contagion. The Journal of Finance 69 (6), 2597-2649

6. Black, F. (1976). The pricing of commodity contracts. Journal of financial economics, 3(1), 167-179.

7. Bollerslev, T. (1987). A conditionally heteroskedastic time series model for speculative prices and rates of return. The review of economics and statistics, 542-547.

8. Bollerslev, T. (1990). Modelling the coherence in short-run nominal exchange rates: a multivariate generalized ARCH model. The Review of Economics and Statistics, 498-505.

9. Calvo, S. G., \& Reinhart, C. M. (1996). Capital flows to Latin America: is there evidence of contagion effects?. World Bank Policy Research Working Paper, (1619).

10. Campbell, J. Y., \& Hentschel, L. (1992). No news is good news: An asymmetric model of changing volatility in stock returns. Journal of financial Economics, 31(3), 281-318.

11. Celık, S. (2012). The more contagion effect on emerging markets: The evidence of DCCGARCH model. Economic Modelling, 29(5), 1946-1959.

12. Charter of the United Nations (1945), United Nations, http://www.un.org/en/documents/charter/.

13. Chiang, T. C., Jeon, B. N., \& Li, H. (2007). Dynamic correlation analysis of financial contagion: Evidence from Asian markets. Journal of International Money and Finance, 26(7), 1206-1228.

14. Chiang, T. C., Jeon, B. N., \& Li, H. (2007). Dynamic correlation analysis of financial contagion: Evidence from Asian markets. Journal of International Money and Finance, 26(7), 1206-1228.

15. Cho, J. H., \& Parhizgari, A. M. (2008). East Asian financial contagion under DCCGARCH. International Journal of Banking and Finance, 6(1).

16. Christie, A. A. (1982). The stochastic behavior of common stock variances: Value, leverage and interest rate effects. Journal of financial Economics, 10(4), 407-432.

17. Claessens, S., \& Forbes, K. (2001). International financial contagion: An overview of the issues and the book. In International financial contagion (pp. 3-17). Springer US. 
18. Claessens, S., \& Forbes, K. (2004, November). International financial contagion: The theory, evidence and policy implications. In Conference "The IMF's role in emerging market economies: Reassessing the adequacy of its resources", Amsterdam.

19. Claessens, S., Dornbusch, R., \& Park, Y. C. (2001). Contagion: Why crises spread and how this can be stopped. In International financial contagion (pp. 19-41). Springer US.

20. Collins, D., \& Biekpe, N. (2003). Contagion: a fear for African equity markets? Journal of Economics and Business, 55(3), 285-297.

21. Corsetti, G., Pesenti, P., Roubini, N., \& Tille, C. (2000). Competitive devaluations: toward a welfare-based approach. Journal of International Economics, 51(1), 217-241.

22. Dimitriou, D., Kenourgios, D., \& Simos, T. (2013). Global financial crisis and emerging stock market contagion: A multivariate FIAPARCH-DCC approach. International Review of Financial Analysis, 30, 46-56.

23. Dimson et al., 2014, Credit Suisse Research Institute 2014 Yearbook, Credit Suisse.

24. Dooley, M., \& Hutchison, M. (2009). Transmission of the US subprime crisis to emerging markets: Evidence on the decoupling-recoupling hypothesis. Journal of International Money and Finance, 28(8), 1331-1349.

25. Dornbusch, R., Park, Y. C., \& Claessens, S. (2000). Contagion: understanding how it spreads. The World Bank Research Observer, 15(2), 177-197.

26. Dungey*, M., Fry, R., González-Hermosillo, B., \& Martin, V. L. (2005). Empirical modelling of contagion: a review of methodologies. Quantitative Finance, 5(1), 9-24.

27. Dungey, M., \& Gajurel, D. (2014). Equity market contagion during the global financial crisis: Evidence from the world's eight largest economies. Economic Systems, 38(2), 161-177.

28. Dungey, M., Milunovich, G., \& Thorp, S. (2010). Unobservable shocks as carriers of contagion. Journal of Banking \& Finance, 34(5), 1008-1021.

29. Economist Intelligence Unit, 2014, Industry Briefing, Fallout from the rouble crisis in Central Asia.

30. Eichengreen, B., Rose, A. K., Wyplosz, C., Dumas, B., \& Weber, A. (1995). Exchange market mayhem: the antecedents and aftermath of speculative attacks. Economic policy, 249-312.

31. Eichengreen, B., Rose, A. K., \& Wyplosz, C. (1996). Contagious currency crises (No. w5681). National Bureau of Economic Research.

32. Engle, R. (2002). Dynamic conditional correlation: A simple class of multivariate generalized autoregressive conditional heteroskedasticity models. Journal of Business \& Economic Statistics, 20(3), 339-350.

33. Engle, R. F., \& Kroner, K. F. (1995). Multivariate simultaneous generalized ARCH. Econometric theory, 11(01), 122-150.

34. Engle, R. F., Ng, V. K., \& Rothschild, M. (1990). Asset pricing with a factor-ARCH covariance structure: Empirical estimates for treasury bills. Journal of Econometrics, 45(1), 213-237.

35. Fama, E. F. (1965). The behavior of stock-market prices. Journal of business, 34-105.

36. Favero, C. A., \& Giavazzi, F. (2002). Is the international propagation of financial shocks nonlinear?: Evidence from the ERM. Journal of International Economics, 57(1), 231-246.

37. Forbes, K. J. (2002). How do large depreciations affect firm performance? (No. w9095). National Bureau of Economic Research.

38. Forbes, K. J. (2004). The Asian flu and Russian virus: the international transmission of crises in firm-level data. Journal of International Economics,63(1), 59-92.

39. Forbes, K. J., \& Rigobon, R. (2002). No contagion, only interdependence: measuring stock market comovements. The journal of finance, 57(5), 2223-2261.

40. Gentile, M., \& Giordano, L. (2012). Financial contagion during Lehman default and sovereign debt crisis. Quaderni di Finanza CONSOB, 72, 3-46.

41. Gerlach, S., \& Smets, F. (1995). Contagious speculative attacks. European Journal of Political Economy, 11(1), 45-63.

42. Glick, R., \& Rose, A. K. (1999). Contagion and trade: Why are currency crises regional?. Journal of international Money and Finance, 18(4), 603-617.

43. Goldfajn, M. I., \& Valdés, M. R. O. (1997). Capital flows and the twin crises: the role of liquidity. International Monetary Fund.

44. Grubel, H. G., \& Fadner, K. (1971). The interdependence of international equity markets. The Journal of Finance, 26(1), 89-94. 
45. International Monetary Fund, 2014, IMF Global Financial Stability Report 2014.

46. Ito, T., \& Hashimoto, Y. (2002). High-Frequency Contagion of Currency Crises In Asia», NBER Working Paper No. 9376.

47. Kenourgios, D., Samitas, A., \& Paltalidis, N. (2011). Financial crises and stock market contagion in a multivariate time-varying asymmetric framework. Journal of International Financial Markets, Institutions and Money, 21(1), 92-106.

48. King, M. A., \& Wadhwani, S. (1990). Transmission of volatility between stock markets. Review of Financial studies, 3(1), 5-33.

49. Lee, Sang B., and Kwang Jung Kim, 1993, Does the October 1987 crash strengthen the comovements among national stock markets?, Review of Financial Economics 3, 89-102.

50. Miguel, A., \& Polk, C. (2014). Connected stocks. The Journal of Finance 69(3), 1099-1127.

51. Mink, M., \& De Haan, J. (2013). Contagion during the Greek sovereign debt crisis. Journal of International Money and Finance, 34, 102-113.

52. Missio, S., \& Watzka, S. (2011). Financial contagion and the European debt crisis.

53. Presidential Decree of August 6, 2014 N 560 "On the application of certain special economic measures to ensure the security of the Russian Federation". www.Garant.ru (in Russian).

54. Roll, R. (1992). Industrial structure and the comparative behavior of international stock market indices. The Journal of Finance, 47(1), 3-41.

55. Serwa, D., \& Bohl, M. T. (2005). Financial contagion vulnerability and resistance: A comparison of European stock markets. Economic Systems,29(3), 344-362.

56. Sharpe, W. F. (1964). Capital asset prices: A theory of market equilibrium under conditions of risk*. The journal of finance, 19(3), 425-442.

57. Tse, Y. K., \& Tsui, A. K. C. (2002). A multivariate generalized autoregressive conditional heteroscedasticity model with time-varying correlations. Journal of Business \& Economic Statistics, 20(3), 351-362.

58. Van Rijckeghem, C., \& Weder, B. (2001). Sources of contagion: is it finance or trade? Journal of International Economics, 54(2), 293-308. 


\section{Appendix}

\begin{tabular}{|c|c|c|c|c|c|c|c|c|}
\hline \multirow{2}{*}{ Index } & \multicolumn{2}{|c|}{ GARCH } & \multicolumn{2}{|c|}{ Asymmetric GARCH } & \multicolumn{2}{|c|}{ DCC GARCH } & \multicolumn{2}{|c|}{ VCC GARCH } \\
\hline & AIC & BIC & AIC & BIC & AIC & BIC & AIC & BIC \\
\hline ROM & -8638.175 & -8589.608 & -8320.161 & -8266.197 & -8640.707 & -8597.626 & -8266.111 & -8244.526 \\
\hline BUL & -8853.338 & -8804.771 & $-8467.260^{*}$ & $-8413.297^{*}$ & -8846.056 & -8802.886 & -8410.498 & -8388.912 \\
\hline KZK & -8783.087 & -8734.520 & $-8468.444^{*}$ & $-8414.481^{*}$ & -8779.376 & -8736.206 & -8168.061 & -8146.475 \\
\hline UKR & -8325.331 & -8276.764 & -8036.375 & -7982.412 & -8325.402 & -8282.231 & -7620.770 & -7599.184 \\
\hline CZC & -9475.812 & -9427.245 & -9219.528 & -9165.565 & -9477.207 & -9434.036 & -9022.502 & -9000.917 \\
\hline EST & -8815.807 & -8767.239 & -8665.558 & -8611.595 & -8813.168 & -8769.997 & -8480.075 & -8458.489 \\
\hline HUN & -8573.660 & -8525.093 & $-8280.967^{*}$ & $-8227.004^{\star}$ & -8575.095 & -8531.924 & -8134.744 & -8113.159 \\
\hline POL & -9316.363 & -9267.796 & $-9050.415^{\star}$ & $-8996.452^{*}$ & -9313.394 & -9270.223 & -8885.221 & -8863.636 \\
\hline EM/FM & -11815.570 & -11767.000 & -11466.600 & -11412.640 & -11791.620 & -11748.450 & -11342.010 & -11320.430 \\
\hline BRA & -9762.212 & -9713.645 & $-9465.957^{\star}$ & $-9417.390^{*}$ & -9745.830 & -9702.659 & -9592.798 & -9565.816 \\
\hline IND & -8994.101 & -8945.534 & $-8700.662^{*}$ & $-8646.699^{*}$ & -8971.460 & -8928.289 & -8607.132 & -8585.547 \\
\hline CHN & -9242.935 & -9194.368 & $-8864.459^{*}$ & $-8810.496^{*}$ & -9199.762 & -9156.591 & -8699.909 & -8678.323 \\
\hline TUR & -8709.337 & -8660.770 & $-8512.525^{\star}$ & $-8458.561^{*}$ & -8709.764 & -8666.593 & -8467.334 & -8445.749 \\
\hline JAP & -9589.629 & -9541.062 & $-9347.077^{*}$ & $-9233.114^{*}$ & -9523.13 & -9479.96 & -9106.269 & -9084.684 \\
\hline RUS & -9294.421 & -9197.287 & -8639.094 & -8574.338 & -9254.713 & -9200.750 & -8414.902 & -8371.731 \\
\hline FRA & -10827.42 & -10778.85 & $-10387.37^{*}$ & $-10333.40^{*}$ & -10791.270 & -10748.100 & -10273.38 & -10251.79 \\
\hline GER & -10922.85 & -10874.28 & $-10595.90^{*}$ & $-10552.73^{*}$ & -10896.82 & -10853.65 & -10418.24 & -10396.65 \\
\hline NED & -10952.53 & -10903.97 & -10626.69 & -10572.72 & -10846.97 & -10803.80 & -10846.97 & -10803.80 \\
\hline UK & -11475.90 & -11427.34 & -11085.86 & -11031.90 & -11409.21 & -11366.04 & -10742.04 & -10720.46 \\
\hline US & -12469.60 & -12421.03 & -11937.06 & -11893.89 & -12381.85 & -12338.68 & -12381.85 & -12338.68 \\
\hline
\end{tabular}

Table A1 AR(1)-GARCH(1,1), Asymmetric GARCH(1,1), DCC and VCC AR(1)-GARCH(1,1) models AIC and BIC. Asterisks indicate statistical significance (alpha=0.05) of asymmetry coefficient for the 19 international markets, during the pre-Crisis period (November 2007-February 2014).

\begin{tabular}{|c|c|c|c|c|c|c|c|c|}
\hline & \multicolumn{2}{|c|}{ GARCH } & \multicolumn{2}{c|}{ Asymmetric GARCH } & \multicolumn{2}{c|}{ DCC-GARCH } & \multicolumn{2}{c|}{ VCC-GARCH } \\
\cline { 2 - 8 } & AIC & BIC & AIC & BIC & AIC & BIC & AIC & BIC \\
\hline ROM & -1875.184 & -1849.447 & $-1874.893^{*}$ & -1838.125 & -1878.329 & -1848.915 & -1876.088 & -1861.381 \\
\hline BUL & -1678.852 & -1645.761 & $-1665.481^{*}$ & $-1628.714^{*}$ & -1671.743 & -1642.329 & -1661.106 & -1646.399 \\
\hline KZK & -1523.934 & -1490.843 & $-1468.552^{*}$ & -1431.784 & -1525.146 & -1495.732 & -1427.172 & -1412.465 \\
\hline UKR & -1114.366 & -1088.629 & -1148.078 & -1118.664 & -1116.261 & -1094.200 & -1045.933 & -1031.226 \\
\hline CZC & -1850.884 & -1817.793 & $-1846.472^{*}$ & $-1809.704^{*}$ & -1852.867 & -1823.453 & -1845.520 & -1830.813 \\
\hline EST & -1838.403 & -1805.313 & -1844.372 & -1807.604 & -1840.266 & -1810.852 & -1839.259 & -1824.552 \\
\hline HUN & -1664.444 & -1631.353 & $-1663.621^{*}$ & $-1626.854^{*}$ & -1663.777 & -1634.363 & -1657.149 & -1642.442 \\
\hline POL & -1461.061 & -1431.647 & $-1913.852^{*}$ & $-1877.084^{*}$ & -1901.856 & -1879.795 & -1902.588 & -1887.881 \\
\hline EM/FM & -2263.18 & -2237.442 & $-2261.742^{*}$ & $-2232.328^{*}$ & -2269.596 & -2240.282 & -2266.327 & -2251.620 \\
\hline BRA & -1536.414 & -1503.323 & $-1497.684^{*}$ & $-1346.593^{*}$ & -1538.376 & -1508.962 & -1522.745 & -1504.361 \\
\hline IND & -1941.854 & -1908.763 & $-1919.037^{*}$ & $-1893.300^{*}$ & -1940.549 & -1911.135 & -1920.462 & -1905.755 \\
\hline CHN & -1857.118 & -1824.027 & -1849.167 & -1812.400 & -1856.853 & -1827.439 & -1844.374 & -1829.667 \\
\hline TUR & -1588.218 & -1555.127 & $-1593.604^{*}$ & $-1556.837^{*}$ & -1590.218 & -1560.804 & -1594.696 & -1579.989 \\
\hline JAP & -1934.863 & -1901.773 & -1908.909 & -1872.141 & -1920.471 & -1891.057 & -1878.100 & -1863.393 \\
\hline RUS & -1469.379 & -1428.934 & $-1446.409^{*}$ & $-1402.288^{*}$ & -1468.791 & -1432.024 & -1403.463 & -1374.048 \\
\hline FRA & -2167.79 & -2134.699 & $-2145.074^{*}$ & $-2108.307^{*}$ & -2159.495 & -2130.081 & -2132.532 & -2117.825 \\
\hline
\end{tabular}




\begin{tabular}{|c|c|c|c|c|c|c|c|c|}
\hline GER & -2071.705 & -2045.967 & $-2058.336^{*}$ & $-2021.568^{*}$ & -2097.932 & -2068.518 & -2049.211 & -2034.504 \\
\hline NED & -2161.622 & -2135.885 & $-2140.341^{*}$ & $-2110.927^{*}$ & -2160.622 & -2138.562 & -2160.622 & -2138.562 \\
\hline UK & -2230.527 & -2204.789 & $-2221.573^{*}$ & $-2192.159^{*}$ & -2229.372 & -22207.311 & -2196.775 & -2182.068 \\
\hline US & -2556.874 & -2531.137 & $-2542.692^{*}$ & $-2530.632^{\circ}$ & -2542.518 & -2521.457 & -2543.518 & -2521.457 \\
\hline
\end{tabular}

Table A2 AR(1)-GARCH(1,1), SAARCH(1,1), DCC and VCC AR(1)-GARCH(1,1) models AIC and BIC. Asterisks indicate statistical significance (alpha=0.05) of asymmetry coefficient for the 19 international markets, during the Crisis period (March 2014-April 2015).
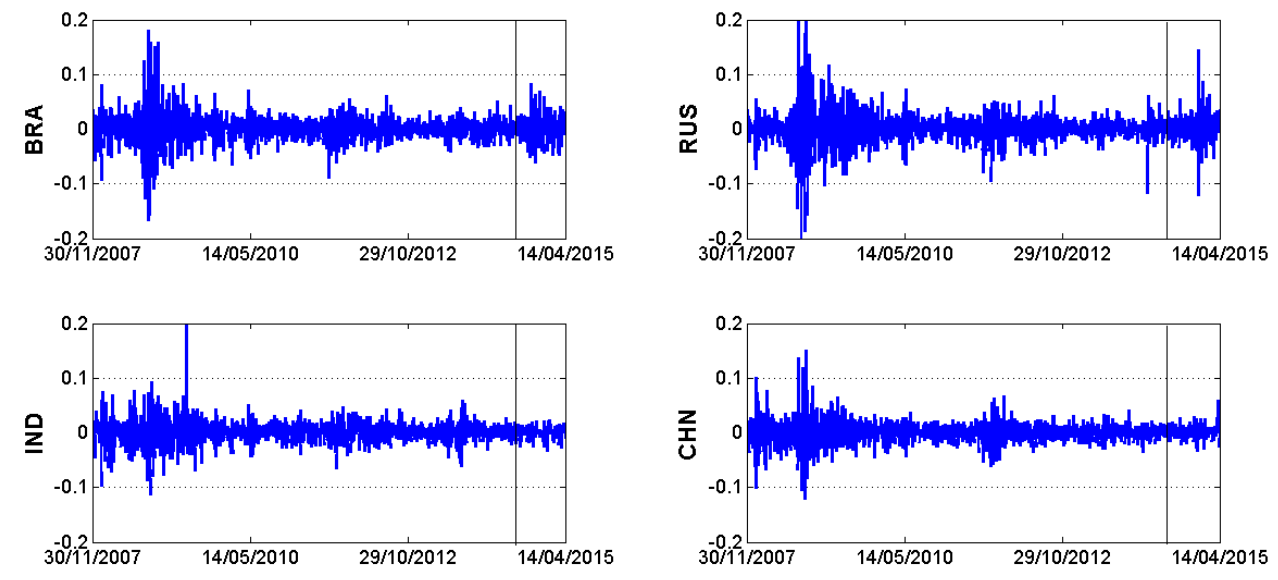

Fig. A1 - Daily stock index returns of the BRIC countries (Brazil, Russia, India, China) over the full studied period, November 30, 2007 to April 15, 2014. The start of the Ukrainian crisis (March 1, 2014) is indicated with a vertical line.
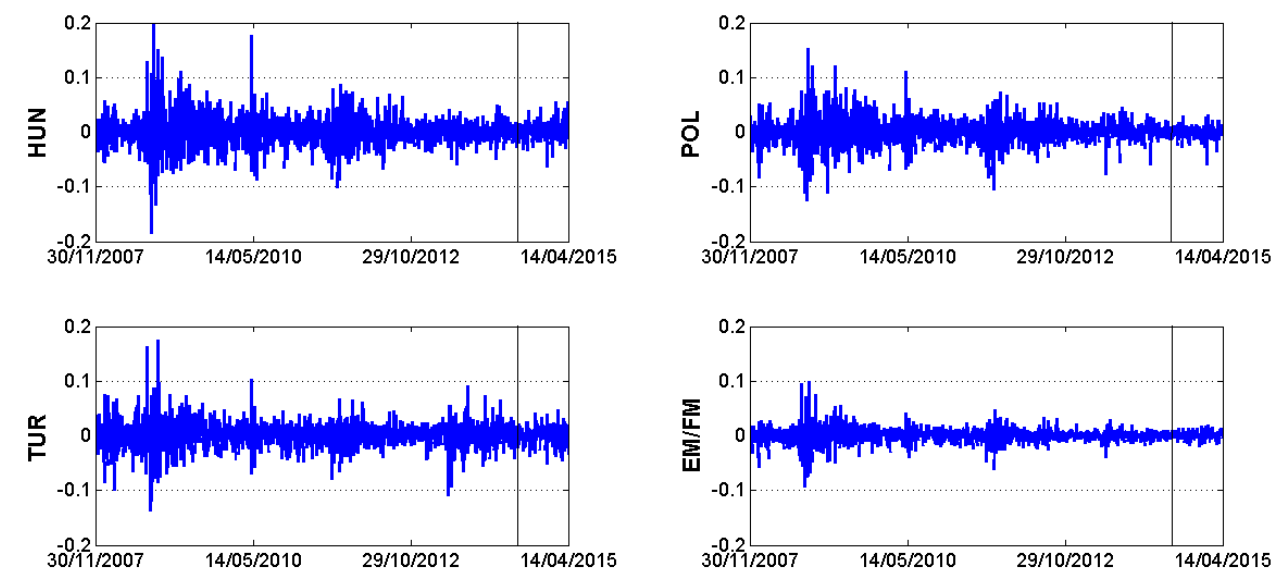

Fig. A2 - Daily stock index returns of the three emerging markets (Hungary, Poland, Turkey) and the MSCl emerging and frontier market index return over the full studied period, November 30, 2007 to April 15, 2014. The start of the Ukrainian crisis (March 1, 2014) is indicated with a vertical line. 

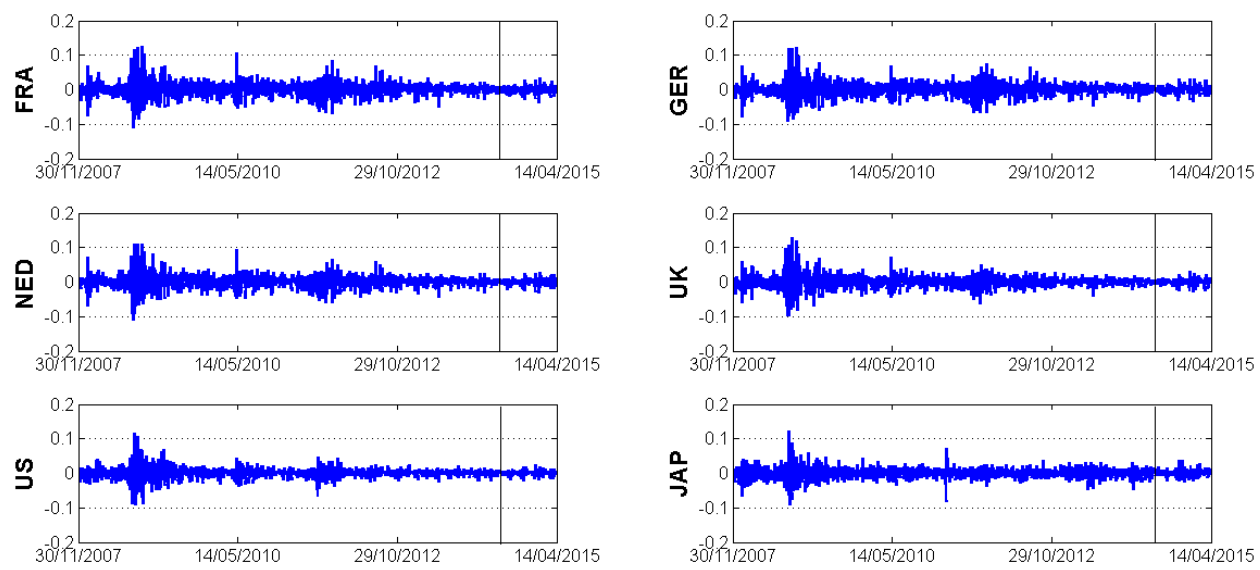

Fig. A3 - Daily stock index returns of the six developed markets (France, Germany, Netherlands, UK, US, Japan) over the full studied period, November 30, 2007 to April 15, 2014. The start of the Ukrainian crisis (March 1, 2014) is indicated with a vertical line.
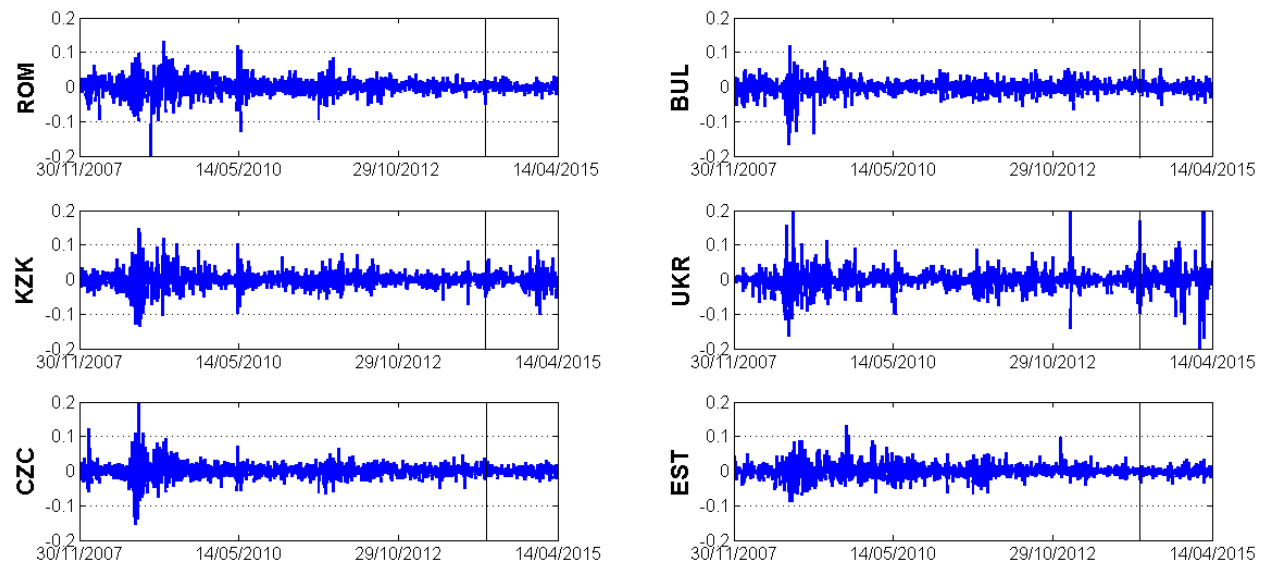

Fig. A4 - Daily stock index returns of the four frontier markets (Romania, Bulgaria, Kazakhstan, Ukraine) and two emerging markets (Czech Republic and Estonia) over the full studied period, November 30, 2007 to April 15, 2014. The start of the Ukrainian crisis (March 1, 2014) is indicated with a vertical line.

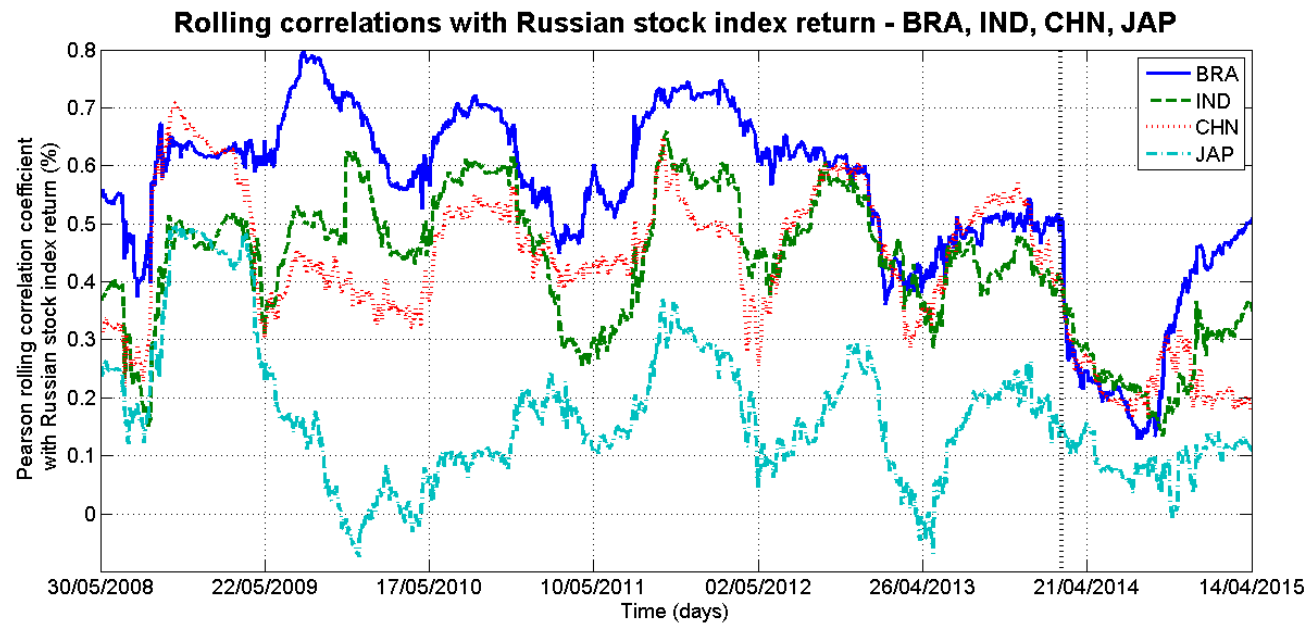


Fig. A5 - Rolling correlations of the Russian stock return and returns in Brazil, India, China, Japan, during the period May 2008-April 2014. The rolling window encloses a 6-month trading period starting in November 2007. The dotted line indicates the start of the 2014 Ukrainian crisis.

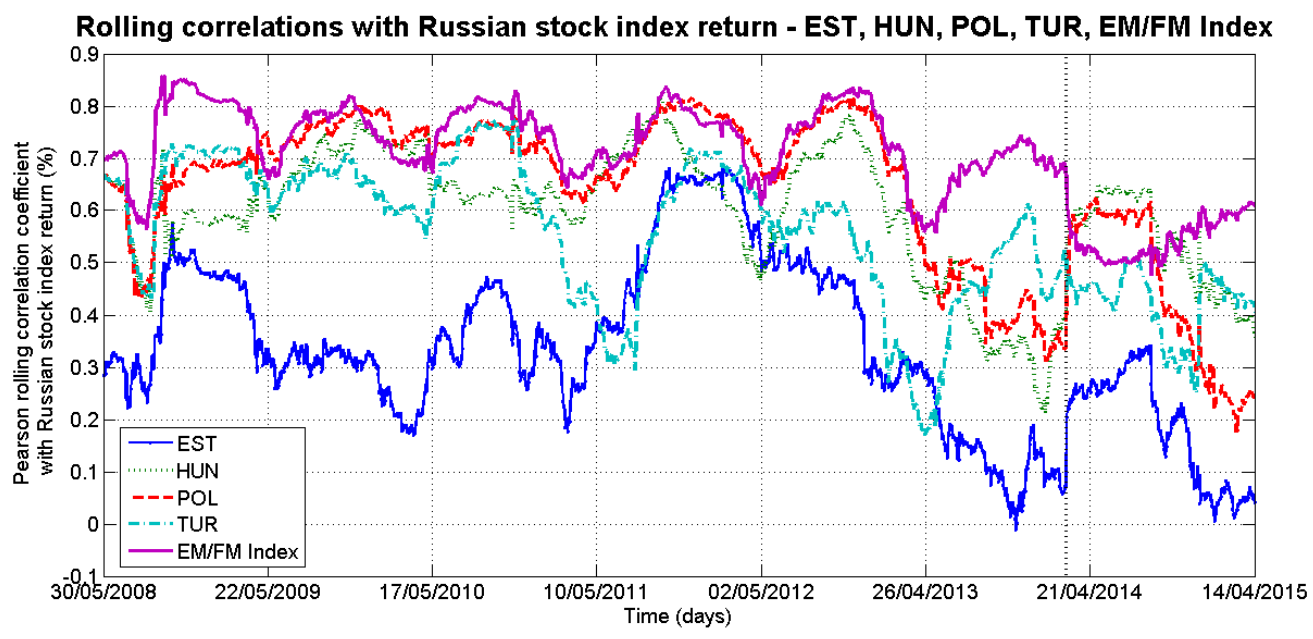

Fig. A6 - Rolling correlation of the Russian stock return and returns in emerging and frontier markets (EM/FM index return), Estonia, Hungary, Poland and Turkey, in the period May 2008-April 2014. The rolling window encloses a 6-month trading period starting in November 2007. The dotted line indicates the start of the 2014 Ukrainian crisis.

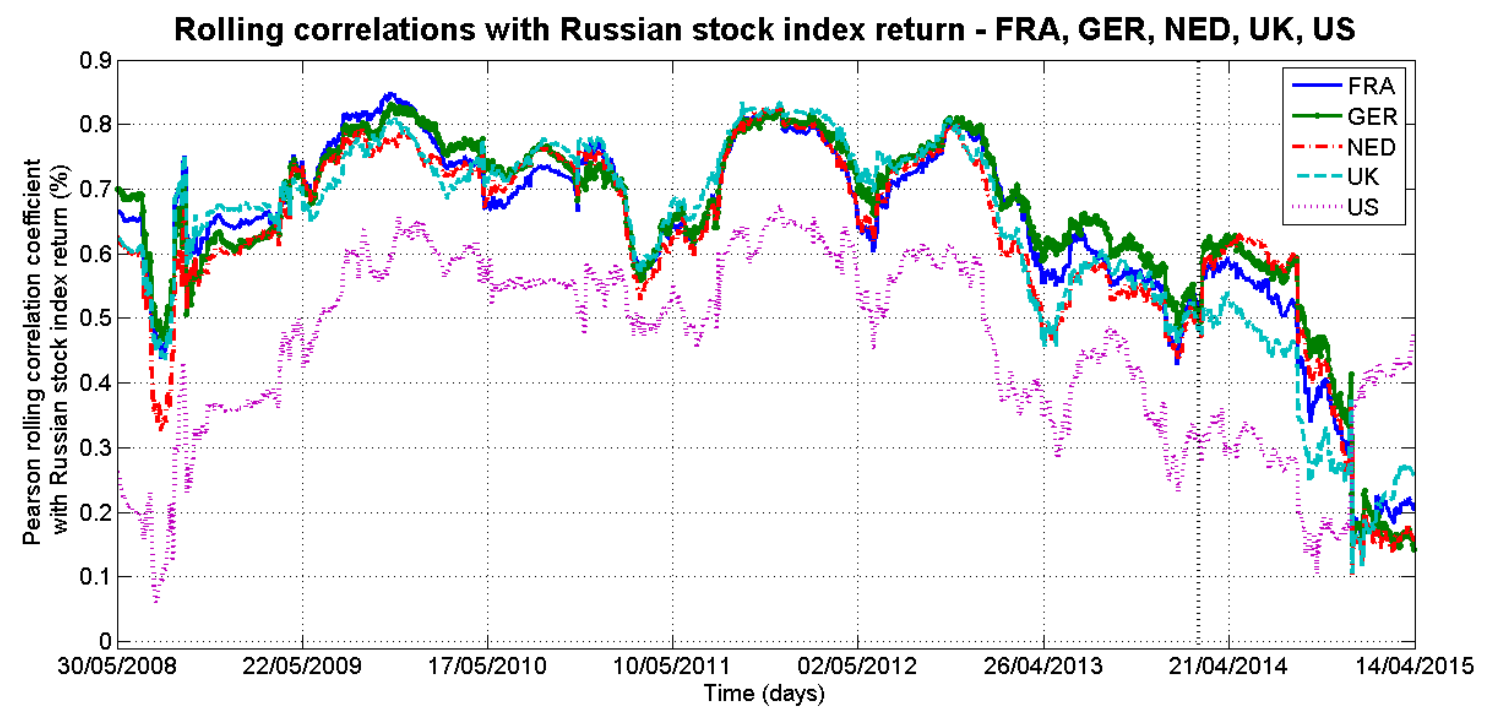

Fig. A7 - Rolling correlation of the Russian stock return and returns in: France, Germany, Netherlands, UK and US, during the period May 2008-April 2014. The rolling window encloses a 6-month trading period starting in November 2007. The dotted line indicates the start of the 2014 Ukrainian crisis. 


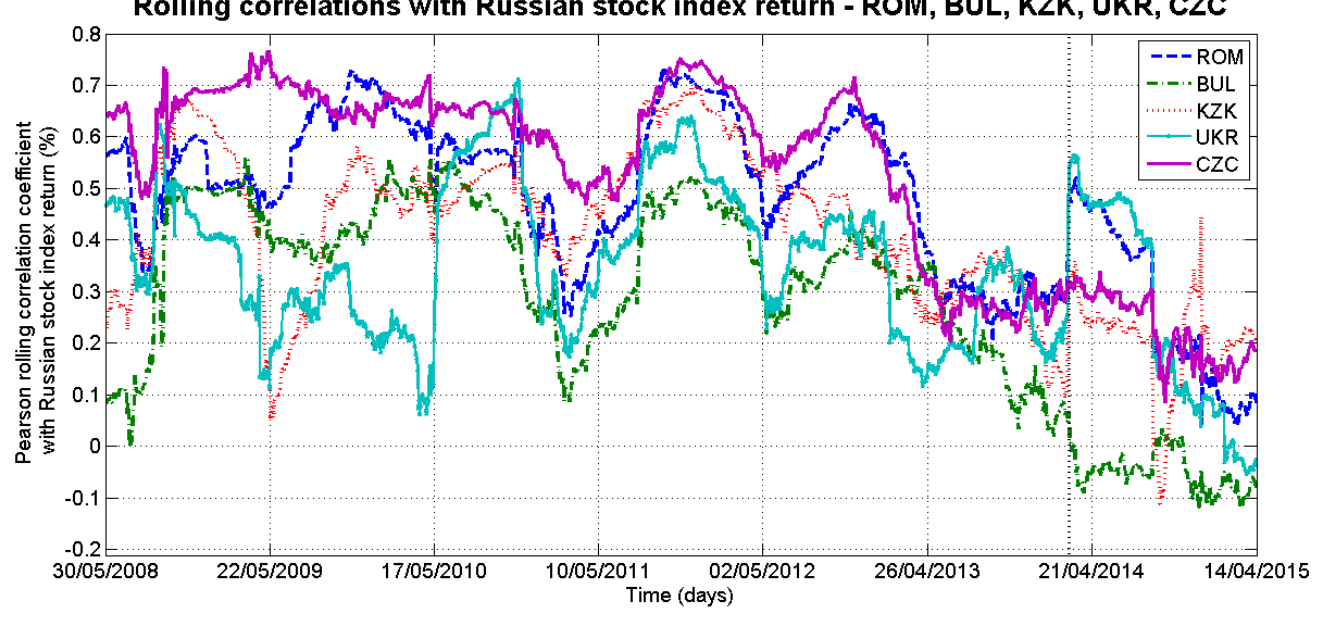

Fig. A8 - Rolling correlations of the Russian stock return and returns in: Romania, Bulgaria, Kazakhstan, Ukraine and Czech Republic, in the period May 2008-April 2014. The rolling window encloses a 6-month trading period starting in November 2007. The dotted line indicates the start of the 2014 Ukrainian crisis.

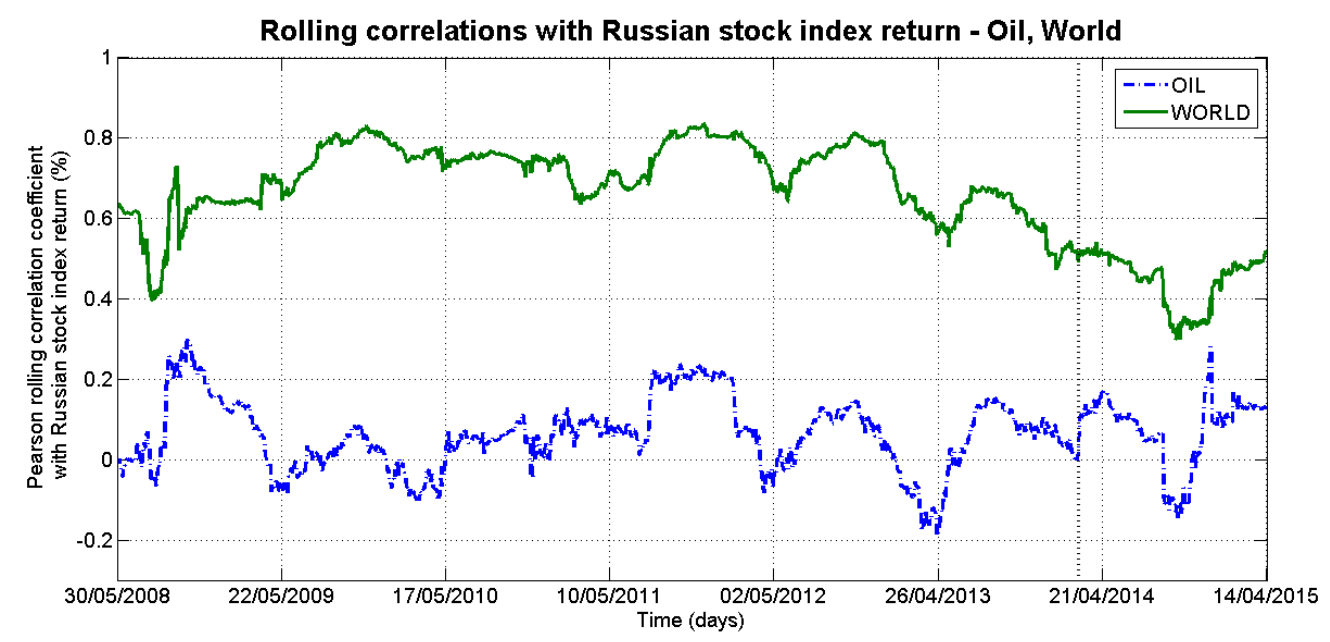

Fig. A9 - Rolling average correlations of daily returns on the MSCI Russia with the Brent crude price returns and the MSCI World Index return, in the period May 2008-April 2014. The rolling 6-month window starts in November 2007. The dotted line indicates the start of the 2014 Ukrainian crisis. 


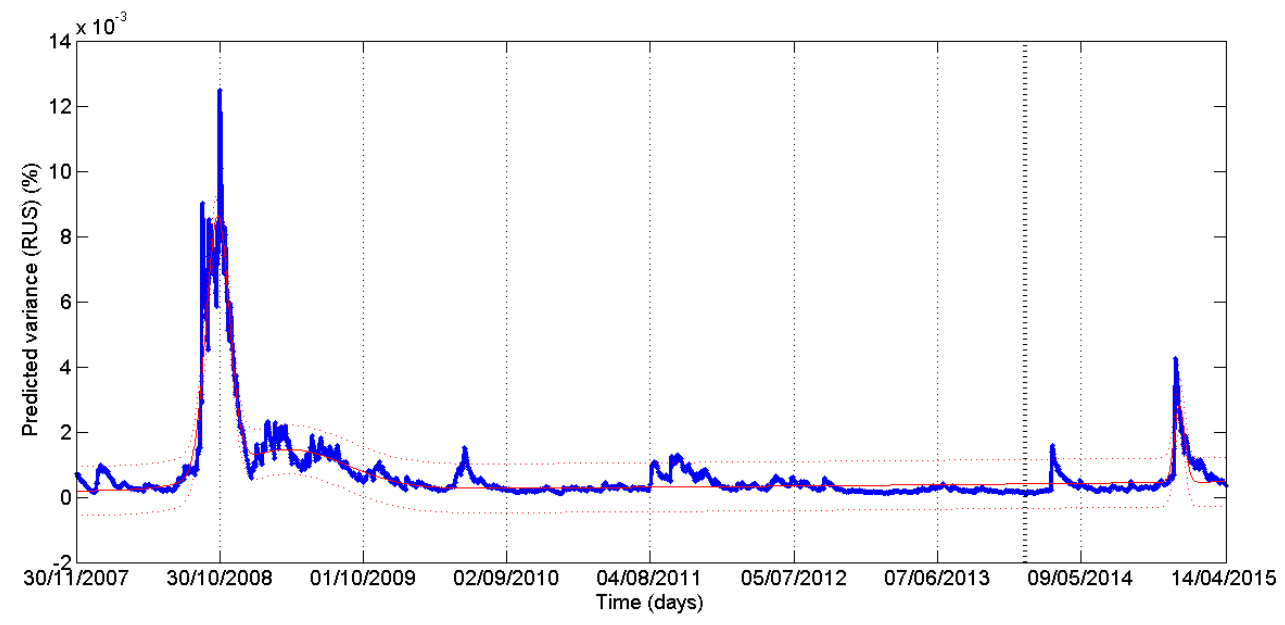

Fig. A10 - AR(1)-MGARCH $(1,1)$ prediction of the variance of Russian stock index return in the period November 2007April 2015, fitted with a fourth-order dynamic polynomial formulation. The dotted line indicates the start of the 2014 Ukrainian crisis. Dynamic 95\% confidence bounds are depicted integration. 